\title{
Monitoring of microbial hydrocarbon remediation in the soil
}

\author{
Chioma Blaise Chikere • Gideon Chijioke Okpokwasili • \\ Blaise Ositadinma Chikere
}

Received: 17 March 2011 / Accepted: 6 June 2011 / Published online: 6 July 2011

(c) The Author(s) 2011. This article is published with open access at Springerlink.com

\begin{abstract}
Bioremediation of hydrocarbon pollutants is advantageous owing to the cost-effectiveness of the technology and the ubiquity of hydrocarbon-degrading microorganisms in the soil. Soil microbial diversity is affected by hydrocarbon perturbation, thus selective enrichment of hydrocarbon utilizers occurs. Hydrocarbons interact with the soil matrix and soil microorganisms determining the fate of the contaminants relative to their chemical nature and microbial degradative capabilities, respectively. Provided the polluted soil has requisite values for environmental factors that influence microbial activities and there are no inhibitors of microbial metabolism, there is a good chance that there will be a viable and active population of hydrocarbon-utilizing microorganisms in the soil. Microbial methods for monitoring bioremediation of hydrocarbons include chemical, biochemical and microbiological molecular indices that measure rates of microbial activities to show that in the end the target goal of pollutant reduction to a safe and permissible level has been achieved. Enumeration and characterization of hydrocarbon degraders, use of micro titer plate-based most probable number technique, community level physiological profiling, phospholipid fatty acid analysis, 16S rRNA- and other nucleic acid-based molecular fingerprinting techniques, metagenomics, microarray analysis, respirometry and gas chromatography are some of the methods employed in bio-
\end{abstract}

C. B. Chikere $(\bowtie) \cdot$ G. C. Okpokwasili

Department of Microbiology, University of Port-Harcourt,

P.M.B. 5323, Port Harcourt, Rivers State, Nigeria

e-mail: ujuazed@yahoo.com

B. O. Chikere

Shell Petroleum Development Company, P. O. Box 230,

Port Harcourt, Rivers State, Nigeria monitoring of hydrocarbon remediation as presented in this review.

Keywords Bioremediation - Hydrocarbon .

Microbial diversity $\cdot$ Molecular techniques

\section{Introduction}

Environmental pollutants can either be organic or inorganic. Quantitatively, the organic pollutants of most concern are hydrocarbons in their various forms. The most common are petroleum hydrocarbons which include $n$-alkanes and other aliphatics, aromatic compounds and other minor constituents (Atlas and Philp 2005; Sarkar et al. 2005). The refining, storage and distribution of crude oil and allied petroleum products are all point sources of soil and water pollution (van Hamme et al. 2003; Chikere et al. 2009a, b; Nogales et al. 2011). Biodegradability of hydrocarbons and hence their degree of persistence in natural environments are influenced by various factors, most vital of which are the chemical structure of the hydrocarbons, the presence of viable microbial population able to degrade them and environmental conditions optimal for microbial degradative activities (Bundy et al. 2002, 2004; Stroud et al. 2007). The process of bioremediation defined as the use of microbes to detoxify or remove pollutants, which relies upon microbial enzymatic activities to transform or degrade offending contaminants, has been greatly used in hydrocarbon mitigation (Roling et al. 2004; Margesin et al. 2007; Wolicka et al. 2009). Bioremediation, especially when it can be carried out in situ, offers a costeffective means of pollutant cleanup. It is an enhancement of the natural fate of biodegradable pollutants and therefore a green solution to the problem of environmental pollution 
with little or no ecological impact (Cappello et al. 2007; Kumar and Khanna 2010). The end products of ultimate biodegradation (also known as mineralization) such as water and carbon dioxide are innocuous to man and the environment. During hydrocarbon bioremediation, a number of indices are monitored to score the effectiveness of the technology. Use of fundamental chemical analyses for pollutant identification and standard microbiological techniques for quantification of viable microbial populations are the starting points of monitoring. First, the nature of the contaminants must be determined in terms of concentration and chemical nature followed by the nature of the contaminated matrix. Another parameter that is critical during monitoring is the measurement of microbial populations involved in the degradation and environmental factors that influence the rates of microbial metabolism.

\section{Interactions between soil and hydrocarbons}

Crude oil is a complex mixture of hydrocarbons and oil recovered from different reservoirs, which varies widely in compositional and physical properties. Long recognized as substrates supporting microbial growth (Rosenberg et al. 1996), these hydrocarbons are both targets and products of microbial metabolism (van Hamme et al. 2003). Crude oil hydrocarbons can be divided into four classes: the aliphatics, the aromatics, the asphaltenes and the resins. Hydrocarbons differ in their susceptibility to microbial attack and, in the past, have been generally ranked in the following order of decreasing susceptibility: n-alkanes $>$ branched alkanes $>$ low molecular weight aromatics $>$ cyclic alkanes $>$ high molecular weight aromatics (Leahy and Colwell 1990).

Alkanes can be utilized by a large number of bacteria. The actual chain length is of decisive importance. Lower molecular weight alkanes are easily volatilized while midlength $\left(\mathrm{C}_{14}-\mathrm{C}_{20}\right)$ alkanes are non-polar, virtually waterinsoluble hydrocarbons with increasing melting and boiling points as carbon number increases within the molecule. Typically, these alkanes have low aqueous solubilities. For instance, hexadecane has a water solubility of $0.9 \mu \mathrm{g} \mathrm{l}^{-1}$ and is a liquid at room temperature. Collectively, these physicochemical properties mean that mid-length aliphatic hydrocarbons are not readily volatilized or leached from soil. It is well established that interactions between hydrophobic organic contaminants may also be important in controlling their fate and behavior in the soil, involving the interactions with the mineral and organic fractions, which may invariably result in reduction in biological/ chemical availability and then allow these contaminants to persist in the soil. Soil is composed of organic and inorganic components separated by pores containing water or air. The interaction between hydrocarbons and mineral surfaces (clay, silt and sand) are only significant when organic matter content is $<0.1 \%$. Thus, organic matter is very important in the fate and behavior of organic contaminants. Organic matter is divided into two distinct phases: (1) soft carbon (rubbery) which is the expanded, flexible structures having humic and fulvic acids as key components with sorption described as irreversible, and (2) hard carbon (glassy) defined as rigid, condensed structures with humin, kerogen and pyrogenic carbons as commonly identified components. Sorption of hydrocarbons within the glassy region is characterized by irreversible sequestration (Stroud et al. 2007; van Elsas et al. 2007).

The extent to which a chemical partitions into the organic matter is described by the $\mathrm{K}_{\mathrm{ow}}$ (octanol-water partition coefficient). Aliphatic hydrocarbons can strongly partition into organic matter and diffuse into the threedimensional structure of organic matter. Hydrocarbons may be sequestered within the soil through sorption to organic matter and mineral fractions and or diffuse into the three-dimensional structure of the soil (Fig. 1). The degree to which these physical interactions occur increases with time and has been termed 'aging'. For aromatics, their fate in the soil is dependent to a large extent on their molecular size, i.e., the number of aromatic rings. Generally, an increase in the size and angularity of aromatics results in a concomitant increase in hydrophobicity, electrochemical stability, high sorption capacity and persistence in the soil (Kanaly and Harayama 2000; van Hamme et al. 2003).

\section{Interaction between microorganisms and hydrocarbons in the soil}

The use of hydrocarbons as substrates for microbial growth presents special problems to both the microorganisms using them as a source of carbon and energy and to researchers in the field of petroleum microbiology. There are two essential characteristics that define hydrocarbon-oxidizing microorganisms:

1. membrane-bound, group-specific oxygenases and

2. mechanisms for optimizing contact between the microorganisms and the water-insoluble hydrocarbons.

The localization of hydrocarbon-oxidizing bacteria in natural environments has received considerable attention because of the possibility of utilizing their biodegradation potentials in the treatment of oil spills. Because of the enormous quantities of crude and refined oils that are transported over long distances and consumed in large amounts, hydrocarbons have now become a very important class of substrates for microbial oxidation (Rosenberg and 
Fig. 1 Possible interactions between soil matrices and aliphatic hydrocarbons; NAPL, non aqueous phase liquids (Source: Stroud et al. 2007)

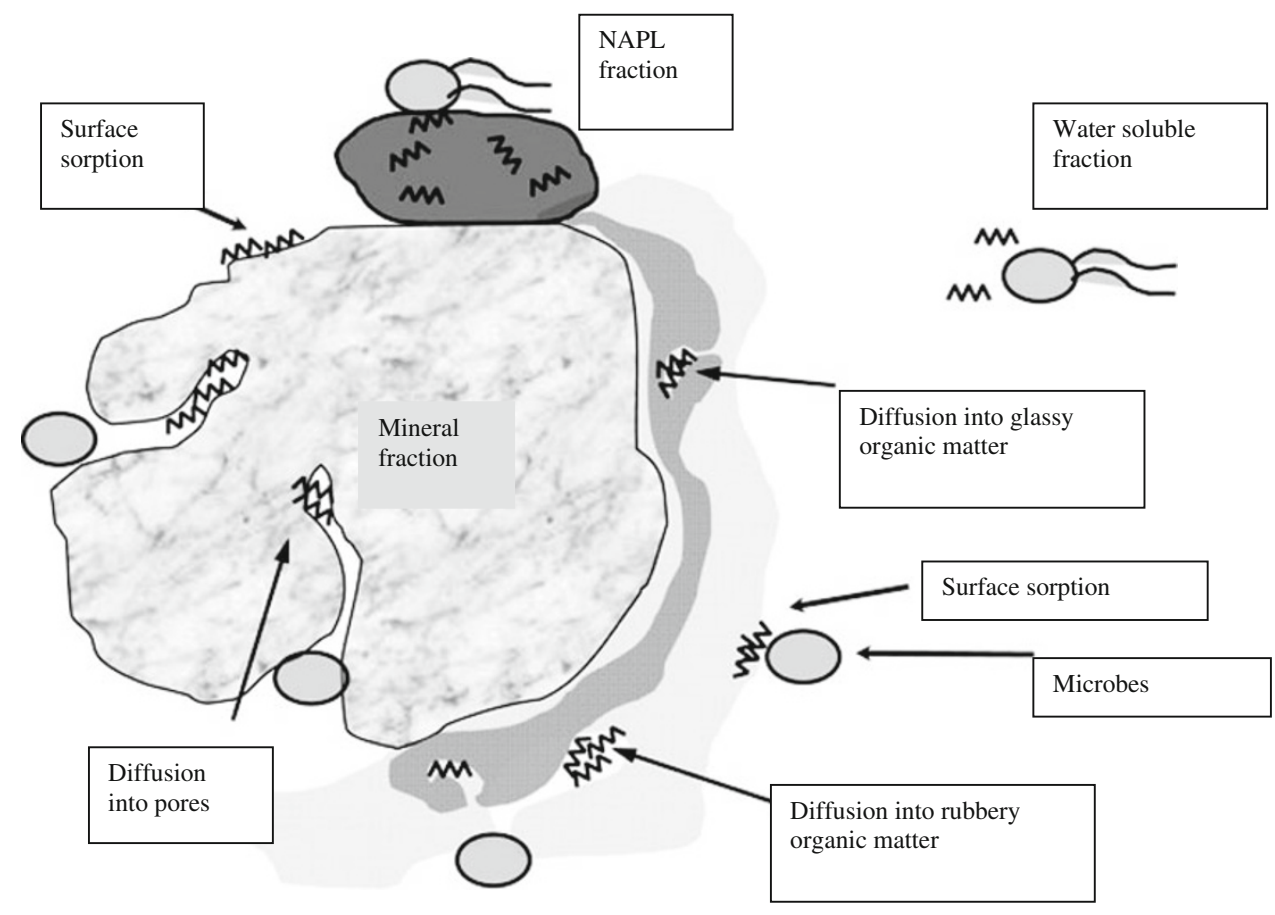

Ron 1996).The biological fate of hydrocarbons in the soil can follow a number of routes. Under ideal conditions, the hydrocarbons are completely mineralized to carbon dioxide and water, with some biomass production. More often, biodegradation is not complete. Microbial metabolism of hydrocarbons to partially oxidized products also serves to remediate polluted soil by fixing and stabilizing potentially hazardous materials. Partially degraded hydrocarbons may become incorporated into the soil organic matter or be humified (Bossert and Compeau 1995). For effective biodegradation to occur, it is therefore essential that the hydrocarbon substrate be 'bioavailable' to the degrading microbial communities (Leahy and Colwell 1990; Rosenberg et al. 1996; van Hamme et al. 2003). Understanding the term 'bioavailability' is complicated because of a number of interpretations in published literature. In an attempt to clarify this matter, Semple et al. (2004) reported two linked definitions, bioavailability and bioaccessibility. A bioavailable compound is defined as one which is freely available to cross an organism's membrane from the medium the organism inhabits at a given point in time, while a bioaccessible compound is described as a compound which is available to cross an organism's membrane from the environment it inhabits, if the organism has access to it. However, it may either be physically removed from the organism, or only bioavailable after a period of time. In considering the methods used to determine microbial degradation as well as the use of chemical extractions to predict microbial degradation in published literature, it is reasonable to presume that the latter definition (bioaccessibility) is more likely to be measured both biologically and chemically.

\section{Microbial ecology of hydrocarbon degradation in the soil}

The ability to metabolize hydrocarbons is displayed by many different types of microbes. There is a myriad of literature on the subject of hydrocarbon degradation by microorganisms and it is now generally accepted that no single species will completely degrade any complex class of hydrocarbons. Although it is widely accepted that bacteria and fungi are primary mediators in hydrocarbon degradation, bacteria have been shown to be more versatile than fungi and therefore may play a greater role during biodegradation of hydrocarbons. Based on published reports, the most important hydrocarbon-degrading bacterial genera in soil environments include Achromobacter, Acinetobacter, Alcaligenes, Arthrobacter, Bacillus, Burkholderia, Collimonas, Corynebacterium, Dietzia, Flavobacterium, Gordonia, Micrococcus, Mycobacterium, Nocardia, Nocardioides, Pseudomonas, Ralstonia, Rhodococcus, Sphingomonas, Variovorax and other unculturable bacterial clones (Leahy and Colwell 1990; Hamamura et al. 2006; Chikere et al. 2009a; Obayori and Salam 2010). Among the fungi, Aspergillus, Candida, Cunninghamella, Fusarium, Mucor Penicillium, Phanerochaete Rhodotorula, Sporobolomyces and Trichoderma are hydrocarbondegrading genera frequently isolated from soil. Fungal hyphal structures and increased surface area allow for better penetration and contact with hydrocarbons. Their extracellular enzymes, e.g., oxidases may further extend their activity into the soil (Young and Cerniglia 1995). Prior exposure to hydrocarbons results in adaptation of the 
microbial community to utilize hydrocarbons as carbon and energy sources. The three interrelated means by which adaptation can occur are (1) induction and or depression of specific enzymes, (2) genetic changes which result in metabolic pathways and (3) selective enrichment of microbes able to transform the hydrocarbons (Leahy and Colwell 1990). Bacteria exhibit these phenomena more than any other microbial group after hydrocarbon perturbation in the soil. Some of the hydrocarbon degradation capabilities that exist in bacteria include possession of degradative plasmids and other mobile genetic elements (Rojo 2009), surfactant production (Van Hamme et al. 2003) and possession of specific catabolic enzymes like oxygenases and hydoxylases (Atlas and Philp 2005). Horizontal gene transfer is more widespread in bacteria and has been reported as one of the major mechanisms responsible for the evolution of enhanced hydrocarbon degradation (Obayori and Salam 2010). Flocco et al. (2009) investigated the diversity of naphthalene dioxygenase genes in soils from Maritime Antarctic using nested PCR, and DGGE cloning and sequencing. Their study revealed the predominance of nahAc-like genes carried on Pseudomonas-associated plasmids in the microbial communities from the hydrocarbon-contaminated soil and quantitative PCR also indicated that their relative abundance increased in response to anthropogenic contamination.

\section{Biodegradation of hydrocarbons in the soil}

Crude oils are composed of complex mixtures of paraffinic, alicyclic and aromatic hydrocarbons. A terrestrial oil spill left to its natural fate is gradually degraded by some biological and non-biological mechanisms (Leahy and Colwell 1990; Atlas and Bartha 1998; van Hamme et al. 2003). Photooxidation may contribute substantially to the self-purification of the soil. Laboratory experiments suggest that in $8 \mathrm{~h}$ of effective sunshine, as much as 0.2 metric ton of oil per square kilometer may be destroyed by photooxidation (Atlas and Bartha 1998). Communities exposed to hydrocarbon become adapted exhibiting selective enrichment and genetic changes resulting in increased proportions of hydrocarbon-degrading bacteria and bacterial plasmids encoding hydrocarbon catabolic genes (Leahy and Colwell 1990; Rosenberg and Ron 1996; Quatrini et al. 2008).

Because adapted microbial communities have higher proportions of hydrocarbon degraders, they can respond to the presence of hydrocarbon pollutants within hours (Atlas and Bartha 1998; van Elsas et al. 2007). A number of uptake mechanisms might be employed by acclimatized microbes during the biodegradation of different components of crude oil as illustrated in Fig. 2. The majority of petroleum hydrocarbons are very hydrophobic and this limits the capacity of microbes, which generally exist in aqueous phase, to access and degrade them. Hydrocarbondegrading microbes can overcome this by producing biosurfactants (van Hamme et al. 2003). For medium and long chain length alkanes, microorganisms may gain access either by adhering to hydrocarbon droplets or by surfactant-facilitated process. Most alkane-degrading bacteria secrete diverse surfactants that facilitate emulsification of the hydrocarbons. Surfactants produced by microbes probably have other roles as well, such as facilitating cell motility on solid surfaces or the adhesion/detachment to surfaces or biofilms (Rojo 2009). The Gram-negative bacterium Acinetobacter is widely known to produce biosurfactants/bioemulsifiers; thus it has a hydrophobic exterior to allow cellular contact with hydrocarbons during biodegradation (Stroud et al. 2007)

\section{Aliphatic hydrocarbons}

Complete degradation of aliphatic hydrocarbons results in the formation of carbon dioxide and water. There are two biodegradation pathways for the alkanes. The initial step in the aerobic degradation of saturated, aliphatic hydrocarbons ( $n$-alkanes) involves the enzymes that have a strict requirement for molecular oxygen, i.e., monooxygenases (mixed function oxidases) or dioxygenases. The most common pathway depends on the action of monooxygenase enzymes and is specific for $n$-alkanes (Stroud et al. 2007). The monooxygenase attacks the terminal methyl group where a primary alcohol is formed (van Hamme et al. 2003). The alcohol is further oxidized to the corresponding aldehyde and fatty acid (pathway 1; Fig. 3).

In the second pathway (Fig. 3), a dioxygenase enzyme acts on the terminal methyl group of an $n$-alkane resulting in the addition of two oxygen atoms. This results in the formation of a peroxide that is converted to a fatty acid. The carboxylic acid groups in the fatty acids resulting from either pathway are then further metabolized via the $\beta$-oxidation pathway (Fig. 3), a common catabolic pathway found in most living cells, to form acetyl CoA or propionyl CoA [depending on the number of carbon atoms (even or odd) in the $n$-alkane]. These compounds are then subsequently metabolized via the tricarboxylic acid cycle (TCA cycle) to $\mathrm{CO}_{2}$ and $\mathrm{H}_{2} \mathrm{O}$ (Atlas and Bartha 1998; van Hamme et al. 2003; van Elsas et al. 2007).

\section{Aromatic hydrocarbons}

Low solubility is one reason for the low rate of biodegradation of aromatic hydrocarbons in addition to problems 
Fig. 2 Range of bacterial uptake mechanisms for hydrocarbons in the soil (Source: Stroud et al. 2007) (a) e.g. Benzylamine $\left(1 \mathrm{kgl}^{-1}\right)$ at a concentration where water solubility is not exceeded

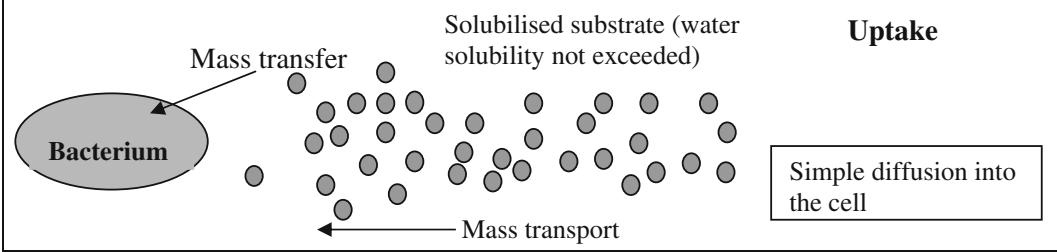

(b) e.g. Naphthalene $\left(30 \mathrm{mgl}^{-1}\right)$ at a concentration where water solubility is not exceeded

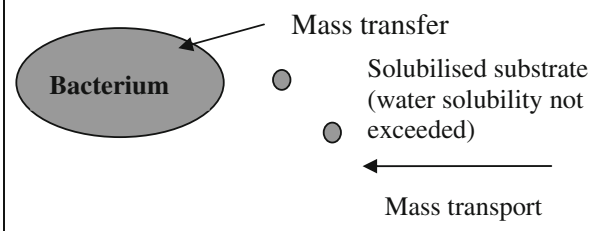

Uptake

Simple diffusion into the cell.

Minimal aqueous phase presence,

therefore mass transport limitations

(c) e.g. Phenanthrene $\left(1.1 \mathrm{mg} \mathrm{l}^{-1}\right)$ at a typical concentration (lower solubility)

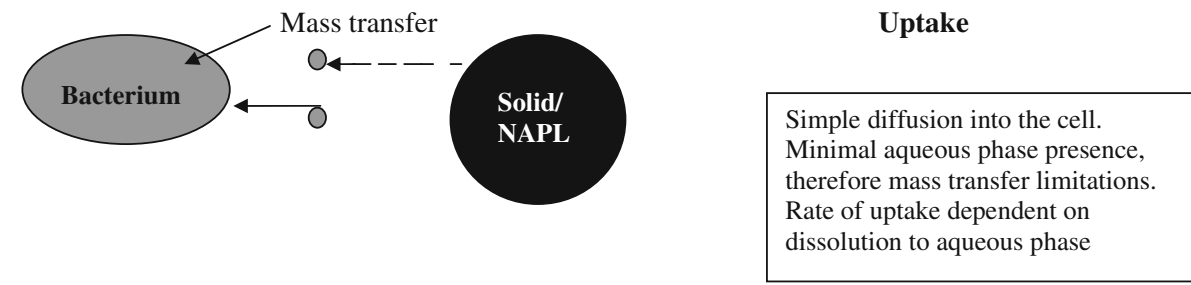

(d) e.g. Hexadecane $\left(0.0009 \mathrm{mg} \mathrm{l}^{-1}\right)$ at a typical concentration (lower solubility)

Uptake

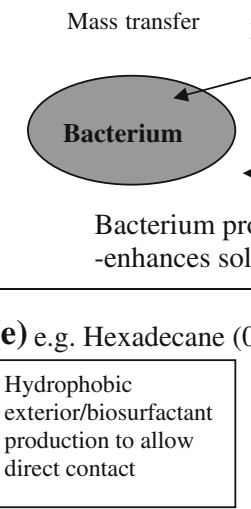

Simple diffusion into the cell. Minimal aqueous phase presence, therefore mass transfer limitations. Rate of uptake dependent on dissolution to aqueous phase.

Microbes have adaptations to overcome

limitations
Fig. 3 Biodegradation of alkanes (Source: van Elsas et al. 2007)

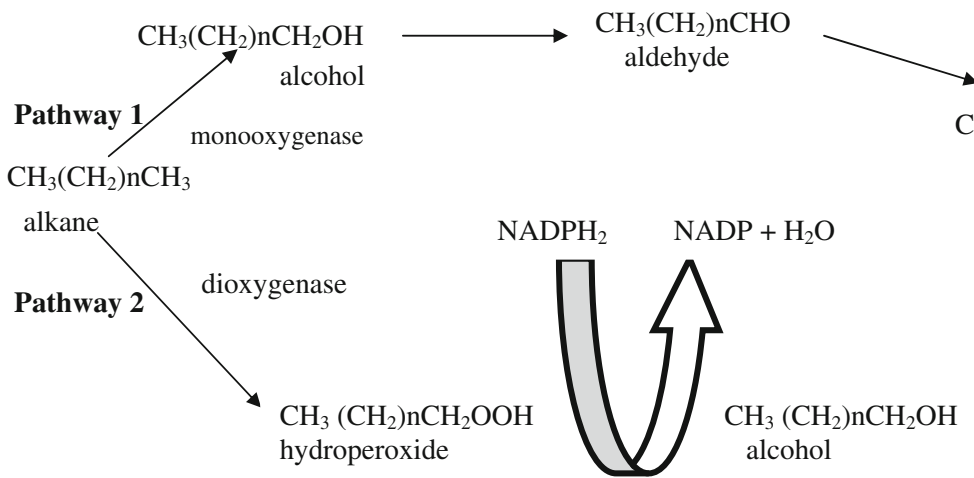

Uptake

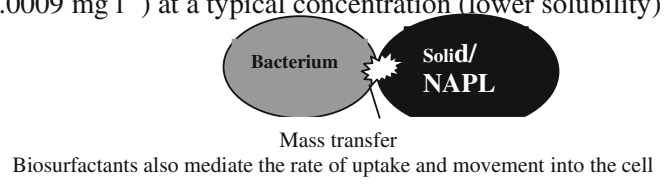

Biosurfactant mediated uptake into cell to minimise mass transfer limitations. Direct contact, therefore minimal mass transport limitations hydroperoxide
$\mathrm{CH}_{3}\left(\mathrm{CH}_{2}\right) \mathrm{nCOOH}$ fatty acid

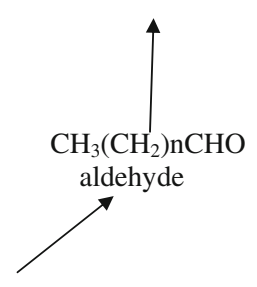


due to production of toxic dead-end metabolites, metabolite repression, presence of preferred substrates and lack of co-metabolic substrates (Kanaly and Harayama 2000; van Hamme et al. 2003; van Elsas et al. 2007). While some simple aromatic hydrocarbons (e.g., BTEX) are present in petroleum, naphthalene, with two aromatic rings, represents the simplest polycyclic aromatic hydrocarbon (PAH). Among the PAHs, the low molecular weight hydrocarbons ( $<3$ rings) are more susceptible to microbial degradation than the high molecular weight PAHs ( $>4$ rings) (Kanaly and Harayama 2000; van Elsas et al. 2007). To date, no single microorganism has been reported that can utilize high molecular weight PAHs such as benzo $(a)$ pyrene as the sole source of energy, although transformations through co-metabolic activities have been reported (van Elsas et al. 2007). Biodegradation mechanisms require the presence of molecular oxygen to initiate the enzymatic attack of PAH rings. In the first step, dioxygenase-catalyzed oxidation of arenes generally takes place in aerobic bacteria to yield vicinal cis-dihydrodiols as early intermediates by a multicomponent enzyme system. These dihdroxylated byproducts may then be cleaved by intradiol or extradiol ringcleaving dioxygenases through either an ortho-cleavage pathway (Fig. 4) or meta-cleavage pathway (Fig. 5), leading to intermediates such as protocatechuate and catechols (Fig. 6; using benzene as an example) (Peng et al. 2008)

Using benzene catabolism as an example (Fig. 6), a dioxygenase facilitates the oxidation of benzene to benzene dihydrodiol, which is subsequently converted to catechol. The catechol aromatic ring is then cleaved, again with the help of a dioxygenase. Catechol catabolism can subsequently follow one of two pathways as described above:

1. The ortho-cleavage pathway, in which the ring is cleaved between the two carbon atoms with hydroxyl groups (Fig. 4).

2. The meta-cleavage pathway, in which the ring splits between adjacent carbon atoms with and without a hydroxyl group (Fig. 5).
Fig. 4 Ortho-cleavage of catechol in the TCA (tricarboxylic acid) cycle (Source: van Elsas et al. 2007)

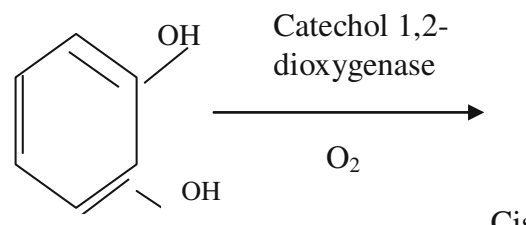

Catechol

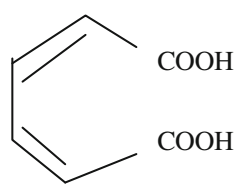

Cis, cis-muconic acid

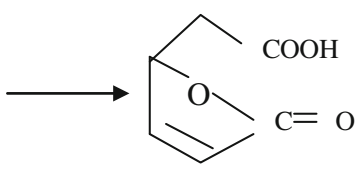

Muconolactone

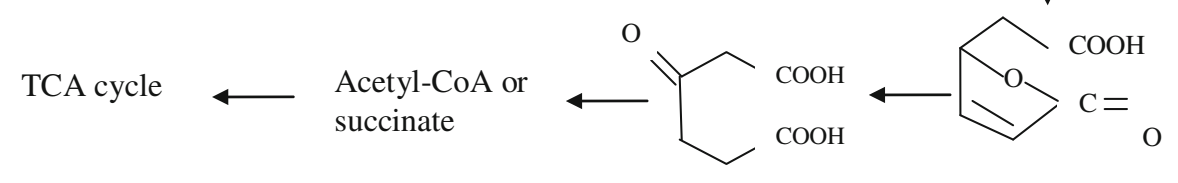

3-oxoadipate

Fig. 5 Meta-cleavage of catechol in the TCA (tricarboxylic acid) cycle (Source: van Elsas et al. 2007)
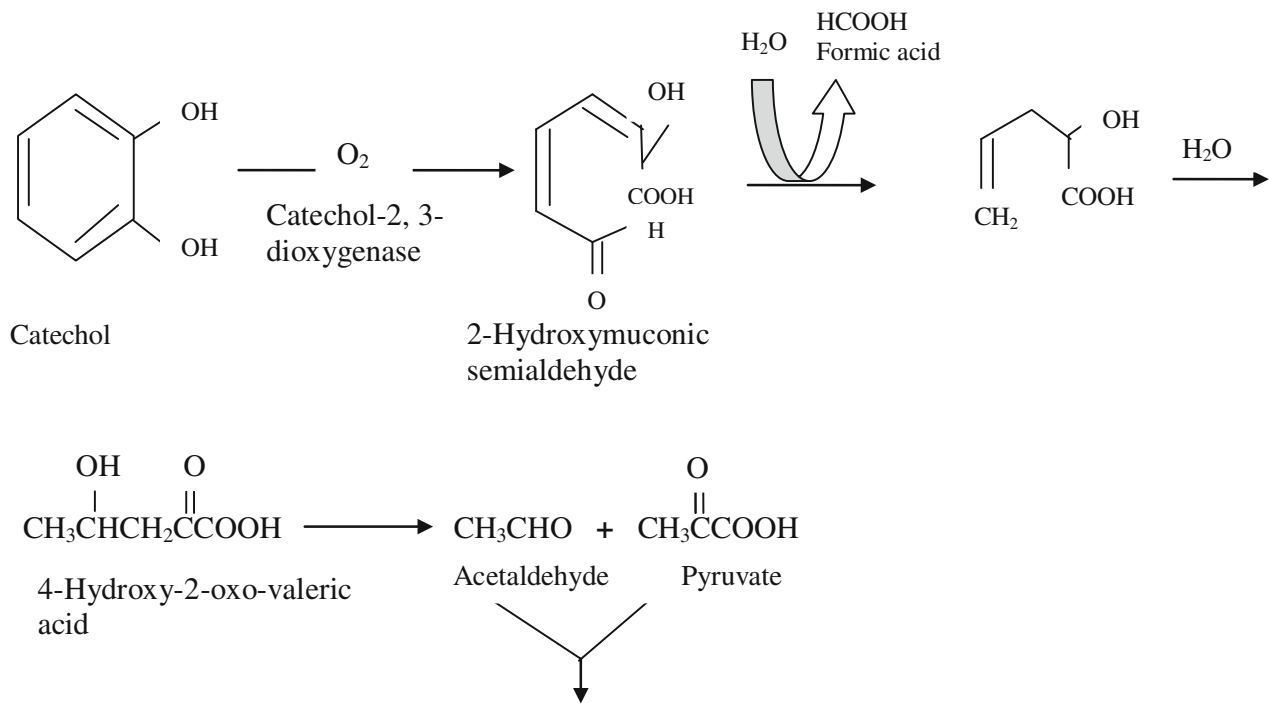

Acetyl CoA $\longrightarrow$ TCA cycle 
Fig. 6 Biotransformation of benzene to catechol. (Source: van Elsas et al. 2007)

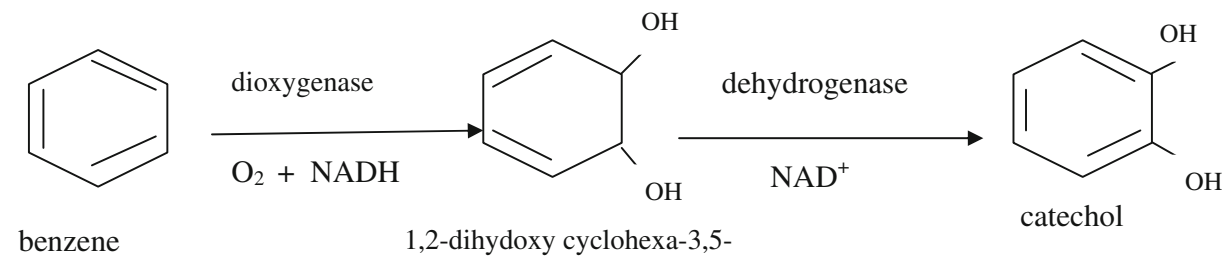

diene
Breakdown metabolites such as acetate, succinate, pyruvate or acetaldehyde from either of the pathways subsequently enter the TCA cycle and are thus available as energy and carbon sources to the cell (Atlas and Bartha 1998; Kanaly and Harayama 2000; Schlegel 2002). Microbial degradation of crude oil has been shown to occur by attack on the aliphatic or aromatic fractions. Although some studies have reported their removal at high rates under optimal conditions (Leahy and Colwell 1990; Rosenberg et al. 1992; Atlas and Bartha 1998; Margesin et al. 2003; Hamamura et al. 2006; Maila et al. 2006, 2008), high molecular weight aromatics, resins and asphaltenes are generally considered to be recalcitrant or exhibit only slow rates of biodegradation (Atlas and Bartha 1998; van Hamme et al. 2003; Stroud et al. 2007).

\section{Soil microbial (bio) diversity}

Biological diversity or biodiversity is defined as the collective variation at all levels of biological organization, from the genetic variations within populations and species, species within communities, to communities that compose an ecosystem (Torsvik and $\emptyset_{\text {vreås 2007). While microbial }}$ diversity on the other hand can be defined as the variety of bacterial species in ecosystems as well as the genetic variability within each species. Biodiversity commonly describes both the information content and how this information is distributed, in biological systems such as microbial assemblages. Taking into account the small sizes of microorganisms, one soil particle of just $1-2 \mathrm{~mm}$ dimension can be compared to a whole landscape for higher organisms and, as such, the origin of the tremendous microbial diversity in the soil and its relation to the processes mediated by the indigenous microbial communities is still poorly understood (Torsvik and Øvreås 2007). Because of this immense genotypic and phenotypic diversity, microbial communities in the soil remain some of the most difficult to characterize (Atlas and Bartha 1998; Maila 2005; Smalla et al. 2007; Malik et al. 2008). Two approaches generally used to characterize microbial diversity include culture-dependent (or phenotypic) or culture-independent (genomic) based techniques. However, due to the heterogeneity of the soil and the inherent limitations of the existing traditional methodologies, most of the bacterial species in the soil remain unidentified. According to literature, in soil ecosystem, in which most of the niches or tasks are fulfilled, microbial diversity is high (Ollivier and Magot 2005; Maila 2005; Smalla et al. 2007; Torsvik and Øvreås 2007; Ge et al. 2008). However, the microbial community structure changes and diversity decreases due to environmental stresses or disturbances (Macnaughton et al. 1999; Atlas and Philp 2005). The reports about the relationship between environmental pollution and the shifts in soil microbial communities are well established together with the phenomenon that changes in community structure usually result in the emergence of dominant populations within the disturbed communities that can survive toxic contamination and have enhanced physiological and substrate utilization capabilities (Miller et al. 2002; Margesin et al. 2003; Zucchi et al. 2003; Evans et al. 2004; Alquati et al. 2005; Vinas et al. 2005; Hamamura et al. 2006; Maila et al. 2006; Popp et al. 2006; Smalla et al. 2007; Ge et al. 2008; Rodrigues et al. 2009; Wolicka et al. 2009; Kumar and Khanna 2010).

Microbe-driven functions are responsible for a wide range of nutrient cycling and geochemical processes in soil. Thus, microbial diversity in soil is crucial for soil functioning and health, and so there is a need to understand at community and species levels the spatial and temporal variability of microbial community structure and functions, e.g., in response to crude oil/hydrocarbon pollution (Macnaughton et al. 1999; Smalla et al. 2007). Crude oil pollution can cause microbial community shifts and a decrease in microbial diversity (Rosenberg and Ron 1996; Hamamura et al. 2006). However, as most of the low molecular weight hydrocarbons are volatile and the high molecular weight alkanes are biodegradable, the impact of hydrocarbons on microbial diversity in soil can be mitigated by bioremediation (Leahy and Colwell 1990; Kaplan and Kitts 2004; Philp et al. 2005). It is therefore important to understand the microbial community structure in the soil, as existing bioremediation technologies can be optimized if the current knowledge of both functional and genetic variability can be improved (Maila 2005; Maila et al. 2006; Lal et al. 2010). 


\section{Methods for monitoring microbial diversity in soil during bioremediation}

For bioremediation to be considered a remediation technology, it is critical to establish that there is an adequate active microbial population that is capable of attacking the specific contaminants (Macnaughton et al. 1999; Chaillan et al. 2004; Maila et al. 2006; Wolicka et al. 2009). If the site has the requisite values for water content and $\mathrm{pH}$, has porosity within the desirable range, and is contaminated with only petroleum hydrocarbons, then there is a very good chance that there will be an active population of hydrocarbon-utilizing bacteria in the soil and that bioremediation may be able to succeed (Atlas and Philp 2005; Ollivier and Magot 2005). Use of fundamental chemical analyses for pollutant identification and standard microbiological techniques for quantification of viable populations of microorganisms are the starting points for monitoring. The techniques for determining the presence of hydrocarbon-utilizing microorganisms are routine, inexpensive and relatively rapid. Even when it is difficult to cultivate specific microbial populations, however, the technique of enrichment culture can reveal the presence of important degrading microbes and establish that they have the natural propensity to degrade the pollutant at an acceptable rate of performance (Williams et al. 1999; Atlas and Philp 2005). There are also emerging techniques of molecular microbial ecology that do not rely on cultivation because of the viable, but nonculturable, phenomenon, which has been found to be very useful for monitoring the progress of bioremediation (Siciliano et al. 2003; Kloos et al. 2006; Brons and van Elsas 2008; Malik et al. 2008; Zengler 2008). During bioremediation, microbial population changes can be investigated, along with more detailed analytical work, e.g., gas chromatograph [(equipped with either of the detectors: flame ionization detector (FID) or electron capture detector (ECD)], high performance liquid chromatography, tests on the fate of ${ }^{14} \mathrm{C}$-radiolabeled substrates to identify specifically whether biodegradation and/or mineralization of the substrate is taking place or a mere transformation to a more or less toxic, more or less mobile metabolite (Okpokwasili et al. 1986; Young and Cerniglia 1995; Atlas and Philp 2005). A number of laboratory- and field-scale bioremediation trials have employed these strategies and found them useful in monitoring the progress of bioremediation in different environmental media (Rosenberg et al. 1992, 1996; Rosenberg and Ron 1996; Macnaughton et al. 1999; Odokuma and Ibor 2002; Odokuma and Dickson 2003; Zucchi et al. 2003; Chaillan et al. 2004; Evans et al. 2004; Ebuehi et al. 2005; Maila et al. 2006; Ayotamuno et al. 2006; Adoki and Orugbani 2007; Stroud et al. 2007; Chikere et al. 2008a, b, Chikere et al. 2009c; Popp et al. 2006; Wolicka et al. 2009).

\section{Microbiological methods}

Monitoring hydrocarbon-utilizing bacteria (HUB)

Crude oil and other petroleum hydrocarbons are chemically heterogeneous and almost ubiquitous in the environment. Not only are they found at the site of oil pollution, but chemical analysis has revealed the presence of both aliphatic and aromatic hydrocarbons in most pristine soils and sediments (Heiss-Blanquet et al. 2005; Ollivier and Magot 2005; Philp et al. 2005; Quatrini et al. 2008). The probable origins of these low concentrations of hydrocarbons in pristine environmental media are seepage from natural deposits and biosynthesis by plants and microorganisms (Atlas and Philp 2005; Ollivier and Magot 2005). It is therefore not surprising that HUB are widely distributed in nature. Several investigations have demonstrated an increase in the number of HUB in oil-polluted habitats undergoing bioremediation (Rosenberg et al. 1992, 1996; Rosenberg and Ron 1996; Bouchez-Naitali et al. 1999; Macnaughton et al. 1999; Williams et al. 1999; Odokuma and Ibor 2002; Margesin et al. 2003; Odokuma and Dickson 2003; Koren et al. 2003; Sei et al. 2003; Siciliano et al. 2003; Bordenave et al. 2004a, b; Chikere and ChijiokeOsuji. 2006; Hamamura et al. 2006; Rojas-Avelizapa et al. 2007; Quatrini et al. 2008; Ruberto et al. 2009). However, previous and recent studies have suggested that despite an increase in the HUB percentage, the biodiversity of the bacterial community may be dramatically reduced, since the presence of hydrocarbons in the environment often leads to selective enrichment of HUB, to the relative detriment of biodiversity (Leahy and Colwell 1990; Rosenberg and Ron 1996; Abed et al. 2002; Evans et al. 2004; Atlas and Philp 2005; Maila et al. 2005; Hamamura et al. 2006; Popp et al. 2006; Quatrini et al. 2008; Rodrigues et al. 2009). To achieve hydrocarbon utilization by bacteria, a number of rate limiting nutritional requirements need to be provided. Hydrocarbons, as their name implies, are composed of hydrogen and carbon; therefore, there is a need to supply all other elements essential for growth in the growth medium (Philp et al. 2005). These growth factors include molecular oxygen for the oxygenases, nitrogen, phosphorus, sulfur and metals like $\mathrm{K}^{+}$and $\mathrm{Na}^{+}$(Leahy and Colwell 1990; Venosa et al. (1996): Atlas and Bartha 1998; Rosenberg et al. 1998; van Hamme et al. 2003; Ollivier and Magot 2005).

The ability to degrade and/or utilize hydrocarbons is exhibited by a wide variety of bacterial genera (Leahy and Colwell 1990). In all, according to Prince (2005), more than 75 validly described genera of bacteria degrade oil and other hydrocarbons in different environmental media. Degraders have been isolated from soils (Bouchez-Naitali et al. 1999; Macnaughton et al. 1999; Williams et al. 1999; 
Odokuma and Dickson 2003; Siciliano et al. 2003; Zucchi et al. 2003; Chaillan et al. 2004; Evans et al. 2004; Nweke and Okpokwasili 2004; Kaplan and Kitts 2004; Alquati et al. 2005; Ebuehi et al. 2005; Vinas et al. 2005; Ayotamuno et al. 2006; Hamamura et al. 2006; Maila et al. 2006; Adoki and Orugbani 2007; Rojas-Avelizapa et al. 2007; Wolicka et al. 2009), oceans, coastal waters, freshwater and marine sediments, lakes, ponds and estuaries (Leahy and Colwell 1990; Rosenberg et al. 1996; Swannell et al. 1996; Watanabe et al. 2000, 2001; Abed et al. 2002; Abu and Chikere 2006; Kasai et al. 2002; Roling et al. 2002; Koren et al. 2003; Sei et al. 2003; Bordenave et al. 2004a, b; Roling et al. 2004; Prince 2005; Prince and Atlas 2005; Allen et al. 2007; Gontang et al. 2007; Yakimov et al. 2007; Quatrini et al. 2008; Qiao and Shao 2010). Hydrocarbon degraders have also been isolated from temperate (Hamamura et al. 2006; Philp et al. 2005), tropical (Okpokwasili and Odokuma 1994; Odokuma and Ibor 2002; Ijah and Antai 2003a, b; Odokuma and Dickson 2003; Chaillan et al. 2004; Nweke and Okpokwasili 2004; Chikere and Chijioke-Osuji 2006; Okpokwasili 2006) and Arctic environments (Margesin et al. 2003; Ruberto et al. 2009). Hydrocarbon-degrading bacteria known to grow on various hydrocarbons including crude oil are presented in Table 1.

The technique chosen for isolation of HUB depends on the hydrocarbons in question. Isolation techniques have in common their need for a solid surface upon which discrete colonies of bacteria can grow. This is important to obtain axenic cultures. Therefore, the starting point is the need for an agar-based mineral salt medium for isolation (BouchezNaitali et al. 1999; Daly et al. 1997; Margesin et al. 2003; Amouric et al. 2006; Hamamura et al. 2006; Rodrigues et al. 2009; Ruberto et al. 2009; Wolicka et al. 2009). To specifically isolate HUB, the hydrocarbons must be provided in the growth medium as the sole source of carbon and energy and no other preferable source (Leahy and Colwell 1990; Odokuma and Dickson 2003; Chikere and Chijioke-Osuji. 2006; Atlas and Philp 2005). A very useful mineral salt medium for HUB enumeration and isolation is Bushnell Haas $(\mathrm{BH})$ agar and it has been used by a couple of researchers for this purpose (Evans et al. 2004; Quatrini et al. 2008).

Enumeration and isolation of culturable hydrocarbonutilizing bacteria (HUB)

It is generally assumed that hydrocarbon-contaminated soil can have high concentrations of hydrocarbons which represent high-calorie sustenance for bacteria; then during bioremediation, there should be a mass proliferation of bacteria. This assumption could be wrong. Before a heterotrophic bacterium can start to grow and multiply, it must expend energy for maintenance of viability, called maintenance energy. This energy is derived from the oxidation of organic compounds. When the supply of the organic compound is large, then total available energy will be in excess of maintenance energy, and therefore growth and multiplication can take place (Atlas and Philp 2005). However, since most hydrocarbons are hydrophobic, the actual supply of the carbon is limited by diffusion from the liquid or solid state into the cell surface (Rosenberg and Ron 1996; Rosenberg et al. 1998; Atlas and Philp 2005). When bioavailable carbon is low in concentration, a relatively larger amount of that carbon is required for maintenance energy and as such there will be a smaller amount available for cell growth and division (van Hamme et al. 2003; Atlas and Philp 2005). This phenomenon is also a reason why bioaugmentation with large number of bacterial cells is unsuccessful; if the introduced bacteria are limited in bioavailable carbon and they have a likelihood of starving to death (Leahy and Colwell 1990; Macnaughton et al. 1999; Odokuma and Dickson 2003; Philp et al. 2005). According to Alexander (1999), at threshold level, all the carbon that reaches and enters the cell will be used for maintenance and none is available for growth and division, thus analytical chemistry results at this juncture will demonstrate contaminant attenuation, whereas microbiological results will show that the population and biomass are not increasing.

A common technique for the isolation of crude oilutilizing bacteria from oil-contaminated soil is the vapor phase transfer in which a mineral salts agar is inoculated with known aliquot of the soil suspension and a filter paper soaked with the crude oil or other hydrocarbons is placed in the lid of the Petri dish (Hamamura et al. 2006; Quatrini et al. 2008). According to Philp et al. (2005), an obvious limitation of this technique is that only a proportion of the total bacterial population that can utilize the vapor phase hydrocarbons can be isolated. This method is likely to underestimate the total crude oil-degrading populations. However, a further criticism of this method is that it cannot be assumed that colonies that appear on the agar plates are really oil degraders, as agar can contain some impurities to allow microbial growth; agar can also absorb volatile nutrients from the air in amounts sufficient to support the growth of many non-oil degrading bacteria (van Hamme et al. 2003; Philp et al. 2005). Hamamura et al., (2006) obtained numerous alkane-degrading bacteria using the vapor phase transfer, which did not correspond to prominent DGGE bands in the oil-contaminated soil they studied. They suggested that results from culture-dependent isolation of hydrocarbon-utilizing bacteria should be confirmed using culture-independent molecular techniques such as denaturing gradient gel electrophoresis of 
Table 1 Genera of bacteria that utilize hydrocarbons as sole source of carbon and energy

\begin{tabular}{|c|c|c|}
\hline Genus & Typical substrate & Degradative genes/enzymes \\
\hline Achromobacter & Gas oil & Alkane hydroxylases \\
\hline Acidecella & Naphthalene & Plasmid-borne genes for dioxygenase \\
\hline Acidovorax & Phenanthrene & Plasmid-borne genes for dioxygenase \\
\hline Acinetobacter & Gas oil & Alkane hydroxylases \\
\hline Actinomyces & Crude oil & Alkane hydroxylases \\
\hline Aeromonas & Diesel oil & Alkane hydroxylases \\
\hline Agrobacterium & Gasoline aromatics & Plasmid-borne genes for dioxygenase \\
\hline Alcaligenes & Gas oil & Plasmid-borne genes for dioxygenase \\
\hline Alcanivorax & Alkanes; crude oil & Alkane hydroxylases \\
\hline Alkanindiges & Alkanes & Alkane hydroxylases \\
\hline Alteromonas & Crude oil & Alkane hydroxylases \\
\hline Arthrobacter & Gas oil & Alkane hydroxylases \\
\hline Aureobacterium & Crude oil & Alkane hydroxylases \\
\hline Azoarcus & Toluene & Plasmid-borne genes for dioxygenases \\
\hline Azospirillum & Jet fuel & Alkane hydroxylases \\
\hline Azotobacter & Crude oil & Alkane hydroxylases \\
\hline Bacillus & Toluene; crude oil & Alkane hydroxylases; plasmid-borne genes for dioxygenases \\
\hline Beijerinckia & Phenanthrene & Plasmid-borne genes for dioxygenases \\
\hline Blastochloris & Toluene & Plasmid-borne genes for dioxygenases \\
\hline Brevibacterium & Alkanes & Alkane hydroxylases \\
\hline Brevundimonas & Fuel oil & Alkane hydroxylases \\
\hline Burkholderia & Toluene & Alkane hydroxylases; plasmid-borne genes for dioxygenases \\
\hline Clavibacter & Naphthalene & \\
\hline Comamonas & Phenanthrene & Plasmid-borne genes for dioxygenase \\
\hline Corynebacterium & Fuel oil; crude oil & Alkane hydroxylases \\
\hline Cyclostaticus & Biphenyl; crude oil & Plasmid-borne genes for dioxygenases \\
\hline Cytophaga & Crude oil & Alkane hydroxylases \\
\hline Dechloromonas & Benzene & \\
\hline Desulfatibacillum & Alkanes & $\begin{array}{l}\text { Enzymology not well understood; alkane activation by addition of } \\
\text { fumarate terminally/subterminally }\end{array}$ \\
\hline Desulfobacterium & Xylene & Chromosomally borne benzyl succinate synthase \\
\hline Desulfobacula & Toluene & Chromosomally borne benzyl succinate synthase \\
\hline Desulfosarcina & Xylene & Chromosomally borne benzyl succinate synthase \\
\hline Desulfosporosinus & Gasoline & $\begin{array}{l}\text { Enzymology not well understood; alkane activation by addition of } \\
\text { fumarate terminally/subterminally }\end{array}$ \\
\hline Dietzia & Alkanes & Alkane hydroxylases \\
\hline Enterobacter & Alkanes & Alkane hydroxylases \\
\hline Erwinia & Alkanes & Alkane hydroxylases \\
\hline Flavobacterium & Diesel oil; crude oil; phenanthrene & Alkane hydroxylases; plasmid-borne genes \\
\hline Geobacillus & Crude oil & Alkane hydroxylases \\
\hline Geobacter & Toluene & Plasmid-borne genes for dioxygenases \\
\hline Gordonia & Alkanes; crude oil & Alkane hydroxylases \\
\hline Klebsiella & Crude oil & Plasmid-borne genes for dioxygenases \\
\hline Lactobacillus & Crude oil & Alkane hydroxylases \\
\hline Leclerica & Pyrene & Plasmid-borne genes for dioxygenases \\
\hline Leucothrix & Crude oil & Alkane hydroxylases \\
\hline Lutibacterium & Phenanthrene & Plasmid-borne genes for dioxygenases \\
\hline Marinobacter & Crude oil & Alkane hydroxylases \\
\hline Micrococcus & Hexadecane & Alkane hydroxylases \\
\hline
\end{tabular}


Table 1 continued

\begin{tabular}{|c|c|c|}
\hline Genus & Typical substrate & Degradative genes/enzymes \\
\hline Moraxella & Biphenyl & Plasmid-borne genes for dioxygenases \\
\hline Mycobacterium & Phenanthrene & Plasmid-borne genes for dioxygenases \\
\hline Neptumonas & Naphthalenes & Plasmid-borne genes for dioxygenases e.g., NAH7 plasmid and its genes \\
\hline Nocardia & Alkanes; crude oil & Alkane hydroxylases \\
\hline Nocardioides & Phenanthrene; crude oil & Alkane hydroxylases \\
\hline Ochrabactrum & Diesel & Alkane hydroxylases \\
\hline Oleiphilus & Alkanes & Alkane hydroxylases \\
\hline Oleispira & Alkanes; crude oil & Alkane hydroxylases \\
\hline Paenibacillus & Phenanthrene & Plasmid-borne genes for dioxygenases \\
\hline Pasteurella & Fluoranthene & Plasmid-borne genes for dioxygenases \\
\hline Peptococcus & Crude oil & Alkane hydroxylases \\
\hline Planococcus & Alkanes; crude oil & Alkane hydroxylases \\
\hline Polaromonas & Naphthalene & Plasmid-borne genes for dioxygenases e.g., NAH7 plasmid and its genes \\
\hline Proteus & Crude oil & Alkane hydroxylases \\
\hline Pseudomonas & Gas oil; crude oil & Alkane hydroxylases; plasmid-borne genes for dioxygenase \\
\hline Ralstonia & Toluene & Plasmid-borne genes for dioxygenase \\
\hline Rhodococcus & Phenanthrene; crude oil & Alkane hydroxylases \\
\hline Sarcina & Crude oil & Alkane hydroxylases \\
\hline Serratia & Crude oil & Alkane hydroxylases \\
\hline Sphaerotilus & Crude oil & Alkane hydroxylases \\
\hline Sphingomonas & Toluene & Plasmid-borne genes for dioxygenases \\
\hline Spirillum & Crude oil & Alkane hydroxylases \\
\hline Staphylococcus & Diesel & Alkane hydroxylases \\
\hline Stenotrophomonas & Pyrene & Plasmid-borne genes for dioxygenases \\
\hline Streptomyces & Alkanes & Alkane hydroxylases \\
\hline Thalossolituus & Alkanes; crude oil & Alkane hydroxylases \\
\hline Thauera & Toluene & Plasmid-borne genes for dioxygenases \\
\hline Thermoleophilum & Alkanes & Alkane hydroxylases \\
\hline Thermoleophilum & Alkanes & Alkane hydroxylases \\
\hline Thermus & Pyrene & Plasmid-borne genes for dioxygenases \\
\hline Terrabacter & Fluorene & Plasmid-borne genes for dioxygenases \\
\hline Vibrio & Phenanthrene & Plasmid-borne genes for dioxygenases \\
\hline Xanthobacter & Dibenzothiophene & Plasmid-borne genes for dioxygenases closely related to NAH7 \\
\hline Xanthomonas & Phenanthrene & Plasmid-borne genes for dioxygenases \\
\hline
\end{tabular}

Sources: Okpokwasili et al. 1986; Watanabe and Hamamura 2003; Ollivier and Magot 2005; Kloos et al. 2006; Peng et al. 2008; Flocco et al. 2009; Obayori and Salam 2010)

polymerase chain reaction-(PCR) amplified genes such as $16 \mathrm{~S}$ rRNA.

\section{Enumeration of unculturable HUB}

It is estimated that $<1 \%$ of environmental isolates are culturable. Fast growing organisms or strains best adapted to particular culture conditions grow preferentially more than those which are not and therefore do not accurately represent the actual community composition actively involved in hydrocarbon degradation. Hence, cultivationdependent characterization of microorganisms during contaminant degradation may limit the scope of microbial biodiversity and the ecological importance of unculturable organisms may go undetected or underestimated (Malik et al. 2008; Rajendhran and Gunasekaran 2011). The genomes of these mainly uncultured species encode a largely untapped reservoir of novel enzymes and metabolic capabilities. Metagenomics bypasses the need for microbial cultivation. Nucleic acid-based methods such as PCR, 
denaturing gradient/temperature gradient gel electrophoresis (DGGE/TGGE) and other microbial typing methods based on rRNA sequences have been used for functional genomic characterization of hydrocarbon degraders. A summary of the different molecular methods used in microbial monitoring of bioremediation is shown in Table 2. Kloos et al. (2006) employed a PCR hybridization method for the detection of alkane monooxygenase homologous genes (alkB) to analyze the diversity of alkB sequences from different soil samples. They found out that alkB sequences detected in the investigated soil samples showed the highest similarities to alkB from Nocardioides, Mycobacterium and Alcanivorax. Chikere (2010) used PCR-amplification of 16S rRNA followed by DGGE and sequencing to characterize bacteria involved in crude oil biodegradation after nutrient enhancement. The findings of the research revealed that members of the Actinobacteria phylogenetic group and some uncultured bacteria were the dominant organisms involved in crude oil biodegradation. A couple of reviews (Watanabe and Hamamura 2003; Peng et al. 2008; Rojo 2009; Obayori and Salam 2010; Nogales et al. 2011) have well articulated cultivation-independent techniques employed in microbial identification during bioremediation of hydrocarbons.

\section{Microtiter plate-based MPN techniques}

As a result of the limitations of the traditional solid agarbased isolation methods, liquid culture methods were developed by using the most-probable number (MPN) procedure (Mills et al. 1978). MPN is a statistical method based upon dilution of a sample to extinction, i.e., multiple replicates of a sample are analyzed and the results compared with statistical tables to determine the MPN of microorganisms in the original sample. The development of 96-well microtiter plates gave the opportunity to miniaturize the method. The sheen screen method introduced by Brown and Braddock (1990), represented the beginning of the miniaturized MPN method for oil degraders. This method was specific for crude oil as a substrate. Wrenn and Venosa (1996) developed a 96-well microtiter plate MPN procedure to separately enumerate aliphatic and aromatic hydrocarbon degraders in separate plates. The alkane degrader MPN method uses n-hexadecane as the carbon source, while growth is scored by turbidity and the reduction of iodonitrotetrazolium violet to iodonitrotetrazolium fromazan (red precipitate) is used as an indicator of electron transport activity. An inherent limitation in the 96-well microtiter plate MPN method is lack of bioavailability of the hydrocarbon. Because of the small confined nature of the wells, both oxygen mass transfer and mixing of the oil and the aqueous phase are limited. This means that the incubation periods are long (usually 2 weeks) and there may be a high risk of wells drying out or the medium may become very saline through evaporation.

Use of enzyme activities to isolate hydrocarbonutilizing bacteria

The enzymes of greatest interest in hydrocarbon degradation are the dioxygenases because of their important roles in substrate activation and aromatic ring cleavage (Atlas and Bartha 1998). Most crude oils contain high concentrations of aromatic hydrocarbons (Ollivier and Magot 2005). Dioxygenase activity can be screened for by the inclusion of indole in mineral salt medium agar plates. Dioxygenases convert indole to indigo and the presence of blue colonies is the selection criterion (Philp et al. 2005). A more specific enzyme screen is for catechol 2,3-dioxygenase. Catechol is an extremely important and common intermediate in aromatic hydrocarbon catabolism (van Elsas et al. 2007). Colonies can be sampled by filter lift from plates sprayed with catechol. The appearance of yellow pigment within 10 min of incubation at room temperature implies catechol 2,3-dioxygenase activity. Alquati et al. (2005) used the catechol color assay to isolate naphthalene degrading bacteria belonging to the genera Rhodococcus, Arthrobacter, Nocardia and Pseudomonas from a petroleum-contaminated soil. In more recent times, primers specific for hydrocarbon-degrading enzymes are used in PCR and other fingerprinting methods in order to elucidate the degradative genes in putative hydrocarbon degraders from petroleum-contaminated soil (Zucchi et al. 2003; Alquati et al. 2005; Higashioka et al. 2009).

\section{Physicochemical methods}

\section{Respirometry}

Metabolic gas respirometry is a technique that gives a rate of reaction by measuring either $\mathrm{O}_{2}$ consumption or $\mathrm{CO}_{2}$ evolution. Radiorespirometry using ${ }^{14} \mathrm{C}$-labeled hydrocarbons, labeled at the most recalcitrant part of the molecule, is more sensitive, yet very expensive, more demanding technically, uses specific hydrocarbons and generates hazardous radioactive waste (Okpokwasili et al. 1986; Philp et al. 2005). Metabolic gas respirometry is much more flexible because of fewer technical constraints associated with this method. However, doubts over the sensitivity of respirometry have been raised especially at sites where the concentration of oxygen is very low. Whereas respirometry is a proven technique for determining biokinetic parameters for biodegradation of contaminants in groundwater, it remains to be successfully used in soils. Oxygen consumption is less sensitive than $\mathrm{CO}_{2}$ evolution 


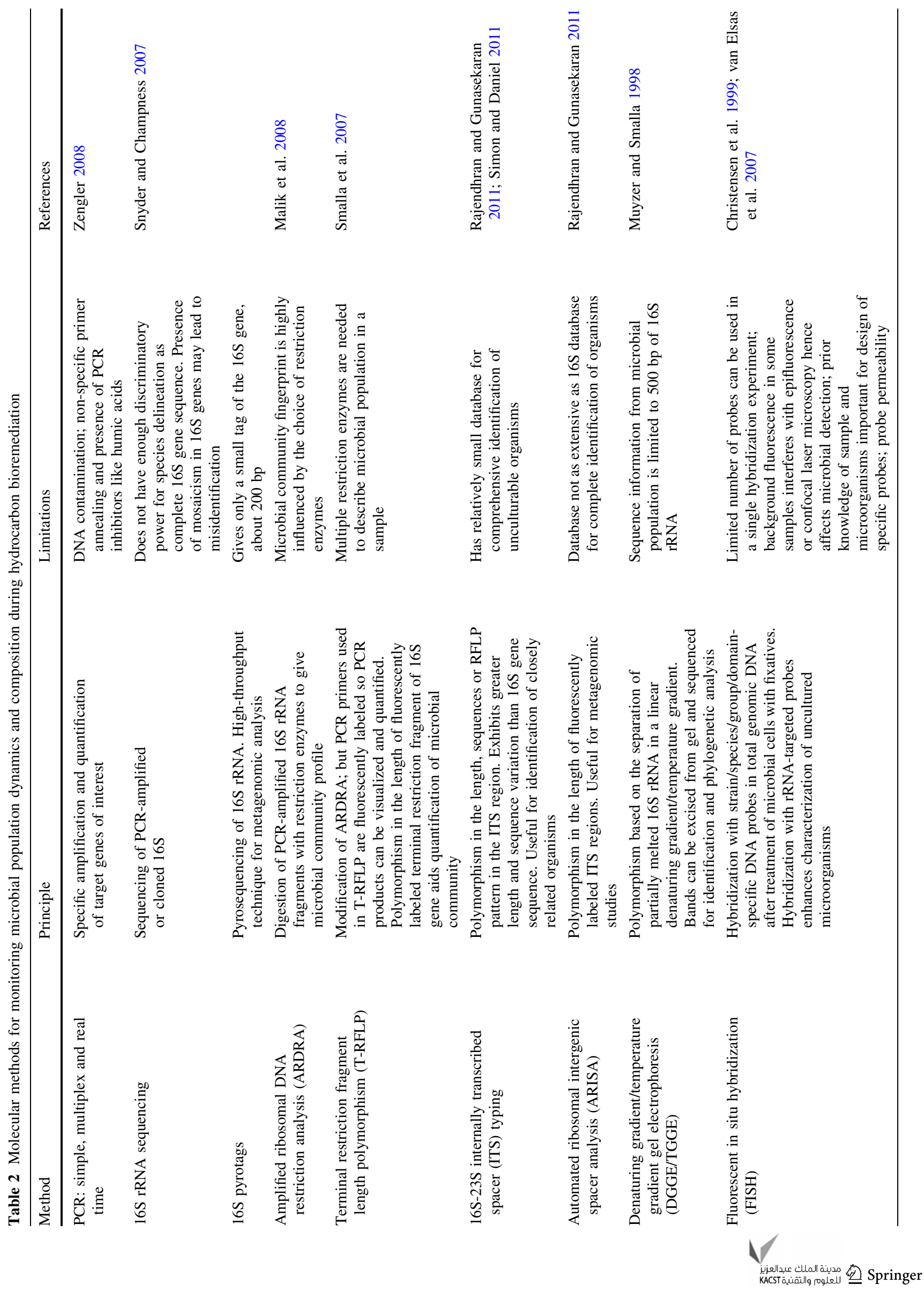




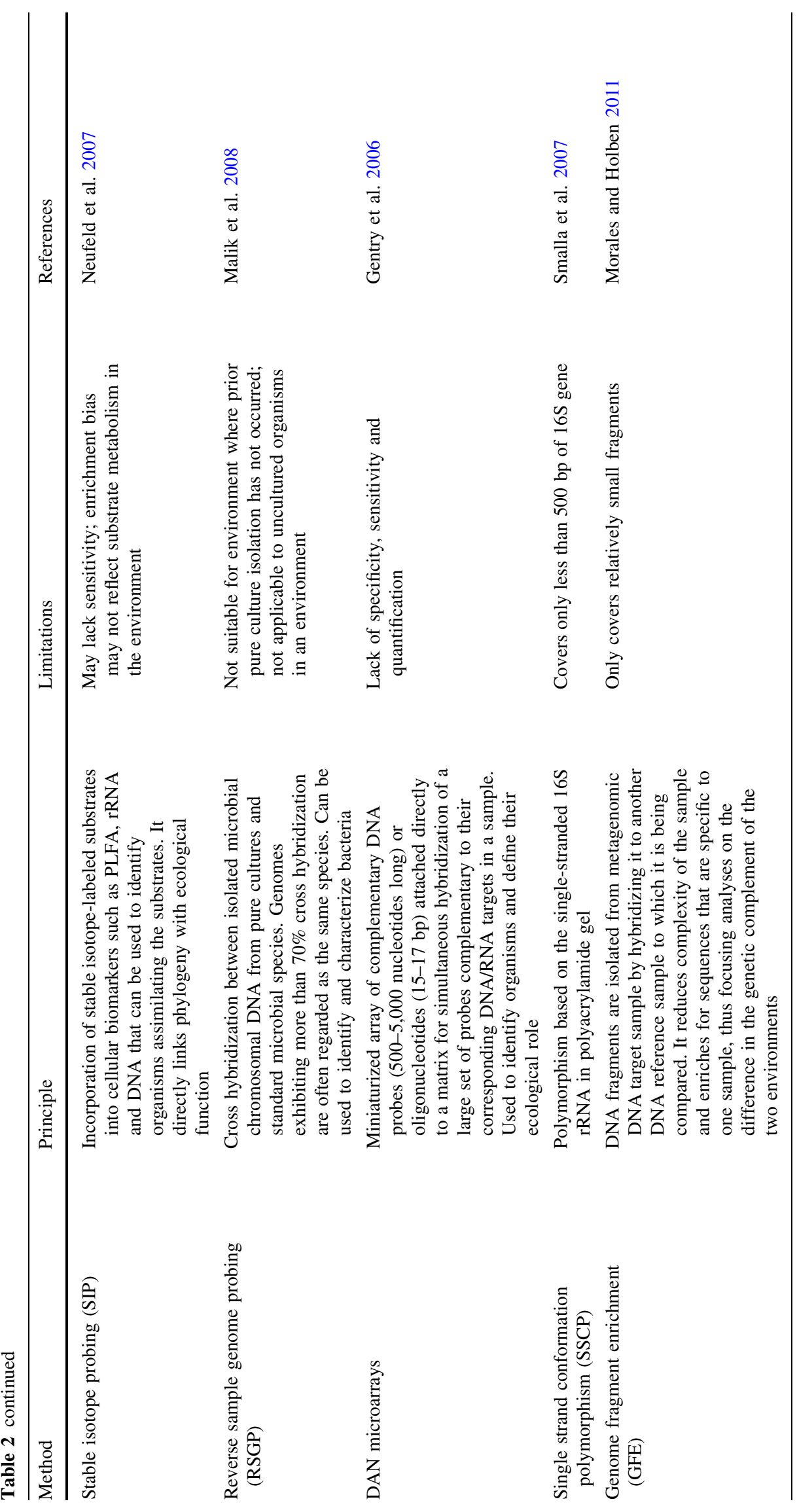


(Philp et al. 2005) as oxygen consumption may arise from biotransformation and not necessarily mineralization. $\mathrm{CO}_{2}$ production, on the other hand, actually provides data on mineralization and is very useful for assessing biodegradability in solid media like soil and sediments (Itavaara and Vikman 1996). Valuable data can be obtained when both $\mathrm{O}_{2}$ consumption and $\mathrm{CO}_{2}$ evolution are measured simultaneously using a GC equipped with concentric columns (Philp et al. 2005). This procedure permits online monitoring and data obtained can be used to establish $\mathrm{O}_{2}$ uptake rate or the $\mathrm{CO}_{2}$ evolution rate together with the respiratory quotient (the ratio of $\mathrm{CO}_{2}$ produced to $\mathrm{O}_{2}$ consumed) (Bellon-Maurel et al. 2003). Okpokwasili et al. (1986) used hexane-dissolved phenanthrene labeled with ${ }^{14} \mathrm{C}$ in the C-9 position to investigate the role of plasmids in the degradation of hydrocarbons in estuarine bacteria namely Escherichia coli HB101, Flavobacterium sp. SB23 and a cured strain of SB23. They found out that plasmid bearing Flavobacterium sp. SB23, which produced clear zones on phenanthrene agar, had greater ${ }^{14} \mathrm{CO}_{2}$ evolution (which evidenced mineralization) than other bacteria with or without plasmid. Bogan et al. (2003) used measurement of ${ }^{14} \mathrm{CO}_{2}$ evolution to monitor the degradation of ${ }^{14} \mathrm{C}$-fluorene and ${ }^{14} \mathrm{C}$-benzo[a]pyrene by a strain of Mycobacterium austroafricanum. Their findings showed that the production of ${ }^{14} \mathrm{C}$ from the radiolabeled hydrocarbons was as a result of mineralization by the bacterium and not due to abiotic factors like photolysis, as the control experiment showed no ${ }^{14} \mathrm{C}$ production. Margesin et al. (2003) used the Isermeyer technique to measure soil respiration $\left(\mathrm{CO}_{2}\right.$ evolution) in petroleum hydrocarbon-contaminated Alpine soils. They used this method to quantify $\mathrm{CO}_{2}$ produced during a $24-\mathrm{h}$ period by titration. Their results correlated positively with the microbiological data obtained attributing the hydrocarbon attenuation observed to microbial activities rather than abiotic losses. In the same vein, Siciliano et al. (2003) used ${ }^{14}$ C-labeled hexadecane, naphthalene and phenanthrene to assess the potential of soil microorganisms to degrade these hydrocarbons during a phytoremediation field trial. They recorded significant mineralization around the rhizospheres of selected plants used in their study, which was in consonance with the results obtained from catabolic gene probe analysis and DGGE analysis of the rhizosphere microbial community. Zucchi et al. (2003) used $\mathrm{CO}_{2}$ evolution from a crude oil-polluted soil to monitor oil degradation in 11 jars equipped with a 50-ml beaker containing $10 \mathrm{ml} 1 \mathrm{M} \mathrm{KOH}$ to trap the evolved $\mathrm{CO}_{2}$. The trapped $\mathrm{CO}_{2}$ in the $\mathrm{KOH}$ solution was quantified by back titration with $1 \mathrm{M}$ $\mathrm{HCl}$ using a radiometer. Their results also correlated positively with the microbiological/molecular data obtained using internal transcribed spacer homoduplex heteroduplex polymorphisms (ITS-HHP) fingerprinting of total soil bacterial DNA and PCR-amplification of the catechol-2,3- dioxygenase (C23O) genes. Amouric et al. (2006) monitored the biodiversity of hexadecane-degrading consortium in a biofilter using $\mathrm{CO}_{2}$ evolution. They measured $\mathrm{CO}_{2}$ concentration contained in the outlet of the biofilter with thermal conductivity detector gas chromatograph. Their results confirmed that the isolated consortium belonging to Actinomycetes demonstrated high degradation of hexadecane as also recorded using DNA base composition and DNA-DNA hybridization studies. Hamamura et al. (2006) also used the production of ${ }^{14} \mathrm{CO}_{2}$ from ${ }^{14} \mathrm{C}$-hexadecane to study the microbial population dynamics associated with crude oil biodegradation in diverse soils. Their findings showed that specific bacterial populations were responsible for the degradation of the hydrocarbons in the crude oil as recorded using radiorespirometry and DGGE analysis of PCRamplified 16S rRNA gene.

\section{Biochemical methods}

\section{Community level physiological profiling (CLPP)}

Community level physiological profiles provide an indication of the metabolic diversity/fingerprint (substrate utilization pattern) present in an environment with respect to the number of defined substrates that can be oxidized by the autochthonous bacteria found there (Maila 2005). Basically, here the diversity unit is the ability of the whole microbial community to degrade specific substrates (range of sugars, carboxylic acids, amino acids and peptides) to provide an unparalleled wealth of discriminating biochemical characterizations. The community level carbon source utilization pattern obtained can be analyzed by applying the Biolog (Biolog, Inc., Hayward, CA, USA; http://www.biolog.com) tetrazolium-based redox dye technology. The method uses 96-well microplates/ ecoplates containing 31 or 95 different carbon sources (Torsvik and Øvreås 2007) for Gram-negative and Grampositive bacteria. The characteristic substrate utilization pattern or 'metabolic fingerprint' produced by the microbial community extracted from the soil or any other environmental sample can thus provide a measure of the community metabolic potential. Pure cultures can as well be identified using different Biolog automated systems coupled with a wide range of identification profiles/databases of different reference microorganisms. Such systems include the MicroLog1 (manual system) MicroStation ID (semi automated system) and OmniLog ID (fully automated) systems (http://www.biolog.com). The results from the CLPP analysis can be further used to describe the community's functional diversity using diversity indices like the Shannon-Weaver index or statistical tools like the principal component analysis (PCA) (Torsvik and Øvreås 
2007). Miller et al. (2002) used CLPP to study the diversity and function of soil bacteria exposed to mercury and tylosin. Their results showed that these contaminants reduced the bacterial diversity which correlated with that obtained with DGGE. In the same vein, Bundy et al. (2004) used CLPP to monitor the recovery of an oil-polluted soil after bioremediation and reported that oil contamination reduced microbial diversity but increased catabolic diversity by selecting for competitive, generalists bacterial populations able to degrade hydrocarbons. Maila et al. (2006) investigated the influence of geographic location and different hydrocarbon pollutants on soil microbial communities using CLPP. They found out that all the hydrocarboncontaminated soils from different locations clustered together having demonstrated similar substrate utilization patterns. They concluded that hydrocarbons rather than geographic location were more important in determining the functional or species diversity within bacterial communities in oil-contaminated soils. Despite the usefulness of the CLPP method in microbial diversity studies, it has shortcomings due to its dependence on culturing and the fact that it gives functional rather than structural information about microbial species in polluted environments (Bundy et al. 2004; Maila 2005).

\section{Phospholipids fatty acids (PLFA) analysis}

Total phospholipids fatty acids extracted from environmental samples have been used to study microbial community structures and metabolic states and to compare similarities and differences among soil microbial communities (Ogram et al. 2007). Phospholipids are important components of living cell membranes and constitute a significant proportion of organism biomass under natural conditions (Kozdroj and van Elsas 2001). Odd numbered and branched-chain fatty acids are associated with Grampositive bacteria, while Gram-negative bacteria on the other hand contain higher proportions of even numbered monosaturated straight chain and cyclopropane fatty acids, eubacteria generally do not contain polyunsaturated fatty acids and plasmalogen phospholipids are enriched in anaerobic prokaryotic bacteria (Ogram et al. 2007). Microorganisms have the ability to change the lipid composition of their membranes in response to environmental conditions such as chemical stress, pollution (Frostegard et al. 1993) and temperature fluctuations (Bartlett 1999). PLFA rapidly degrade upon cell death thus making it a good indicator of living organisms (Drenovsky et al. 2004), and changes in PLFA patterns under environmental stress conditions are a useful biomarker tool to describe the community structure and physiological state of certain microbial taxa (Vestal and White 1989; Misko and Germida 2002). Changes in phospholipid profiles are generally related to the variation in the abundance of microbial groups and this can be interpreted by reference to a database of pure cultures and known biosynthetic pathways (Zelles 1999). The extracted fatty acids are quantitatively analyzed by gas chromatography equipped with mass spectrometry (Zelles and Bai 1993), while comparison of data with information on fatty acids database allows for the identification of extracted PLFAs (Widmer et al. 2001). Although direct extraction of PLFA from soil does not permit delineation down to species level, it is an efficient means by which gross changes in microbial community structure can be profiled (Nannipieri et al. 2003). Several researchers have taken a variety of approaches to the interpretation of community fatty acids profiles (Haack et al. 1994, 2004). Methods such as tabulation of known or presumed unique fatty acids or comparisons of profiles on the basis of within profile ratios of fatty acids have been used (Haack et al. 1994). Currently, PLFA analysis employs the use of multivariate statistics such as PCA to discriminate between composite profiles (Haack et al. 1994; Langworthy et al. 1998; Macnaughton et al. 1999; van Elsas et al. 2007).

Frostegard et al. (1993) examined changes in microbial population profiles in soils artificially polluted with cadmium, copper, nickel, lead or zinc using PLFA. They observed that certain fatty acid patterns characteristic of Gram-positive bacteria were reduced in both forest and arable soils spiked with metals and replaced by PLFA patterns indicative of a Gram-negative bacterial populations. In another independent investigation by Macnaughton et al. (1999) on microbial population changes during the bioremediation of an experimental oil spill, microbial community structures were monitored by PLFA. The results of PLFA analysis demonstrated a community shift in all plots (oil-polluted and unpolluted) from primarily eukaryotic biomass to Gram-negative bacterial biomass with time. PLFA profiles from the oil-polluted plots suggested increased Gram-negative biomass and adaptation to metabolic stress compared to unpolluted controls. Kamaludeen et al. (2003) investigated the ecotoxicity of long-term tannery waste contaminated soils by assessing the bacterial activity and community structure using PLFA. PLFA profiles of specific bacteria decreased significantly as the level of chromium contamination increased, indicating that the concentration of chromium in tannery waste contaminated soil had a significant effect on microbial community structure (Kamaludeen et al. 2003). In another study, a change in microbial community structure during bioremediation of explosives-contaminated soil in a molasses-fed bioslurry process was demonstrated using PLFA profiles (Fuller and Manning 2004). PLFA analysis showed that Gram-positive bacterial populations were more abundant after explosives compounds were reduced 
to non-inhibitory levels (Fuller and Manning 2004). PLFA profiles have also been employed to characterize the microbial community in PAH-contaminated freshwater sediments (Langworthy et al. 1998). Characterization of sulfate-reducing bacteria in groundwater at a uranium mill (Chang et al. 2001) and the study of microbial community structure at uranium-contaminated groundwater sources (Schryver et al. 2006) have been studied using PLFA. Comparison of PLFA and 16S rRNA in a phylogenetic study of 25 isolates of dissimilatory sulfate-reducing bacteria showed highly congruent clustering for 22 isolates (Kohring et al. 1994), thus establishing the usefulness of PLFA in the determination of bacterial relationships. Bundy et al. (2002)used PLFA to study the comparative effect of diesel contamination and simulated bioremediation on the microbial community in different soil types. Their findings showed that there was no tendency for the community structure of the three different soil types to converge as a result of contamination with the same hydrocarbon, rather they became more dissimilar. In another related investigation, Margesin et al. (2007) studied the influence of diesel oil concentration, biostimulation with inorganic/oleophilic fertilizers and incubation time on hydrocarbon removal. Microbial communities as assessed by PLFA patterns were primarily influenced by hydrocarbon content and fertilization. Among bacteria, PLFA indicative of the Gram-negative population were significantly increased $(P \leq 0.05)$ in soil samples containing high concentrations of diesel that received NPK fertilizer. However, PLFA analyses are not without limitations as fatty acid composition can be influenced by temperature and nutrition (Graham et al. 1995). Furthermore, individual fatty acids cannot be used to represent specific species (a single microorganism can have numerous fatty acids and the same fatty acids can occur in more than one species) (Kirk et al. 2004). PLFA as a microbial community profiling tool produces profiles of limited complexity, thus PLFA is often used in conjunction with other molecular profiling methods to assess microbial diversity in contaminated soil and water (Ringelberg et al. 2001).

\section{Molecular methods}

\section{Metagenomic era}

Metagenomic approaches have enabled us to understand the genomic potential of the entire microbial community in an ecosystem by cloning and analyzing microbial community DNA directly extracted from environmental samples. The development of improved DNA extraction methods, cloning strategies, screening techniques and high throughput sequencing methods has led to the emergence of various bioinformatic tools for the analysis and comparison of metagenomic data set with respect to taxonomic and metabolic diversity (Delmont et al. 2011; Morales and Holben 2011; Simon and Daniel 2011).

Estimating the microbial diversity of environmental samples is a major challenge during bioremediation. Ever since the discovery of bacterial pure culture techniques by Robert Koch, microbiological culture techniques have been significantly improved. However, a majority of bacterial species in any environment are still unculturable in the laboratory, due to the lack of knowledge of the real conditions under which these bacteria grow in their natural environment. Unfortunately, only a fraction of the microorganisms involved in the biodegradation of contaminants in soil can currently be cultured in the laboratory. It has been estimated that the microbial community in $1 \mathrm{~g}$ of soil may contain over 1,000 different bacterial species, but $<1 \%$ of these may be culturable. It has also been observed that fast growing organisms or strains best adapted to particular culture conditions grow preferentially than those which are not, and therefore do not accurately represent the actual microbial community composition of contaminated environments. Hence, culture-dependent characterization of microorganisms at contaminated sites may limit the scope of microbial biodiversity (Zengler 2008). The application of molecular techniques to study microbial populations at contaminated sites without the need for culturing has led to the discovery of unique and previously unrecognized microorganisms as well as complex microbial diversity in contaminated soil and water, which shows an exciting opportunity for bioremediation strategies. Nucleic acid extraction from contaminated sites and their subsequent amplification by PCR have proved extremely useful in assessing the changes in microbial community structure by several microbial community profiling techniques. Microbial diversity is considered as a function of the number of different classes (richness) and the relative distribution of individual elements among these classes (evenness). The diversity assessment is generally based on (1) PCR-amplification of $16 \mathrm{~S}$ genes from metagenomic DNA; (2) making 16S gene libraries; (3) sequencing of randomly selected clones; and (4) phylogenetic analysis (Rajendhran and Gunasekaran 2011). The richness and evenness of a community are qualitatively estimated based on the number of unique clones and their relative frequencies. However, the validity of metagenomics-based microbial diversity analysis depends on obtaining representative nucleic acids from entire microbial community. The quality and quantity of the metagenomic DNA influences the microbial community structure. Incomplete cell lysis, DNA sorption to inert matrices, coextraction of enzymatic inhibitors and degradation of DNA at various steps of extraction procedures may influence the microbial 
diversity pattern. In addition, biases may be introduced during PCR-amplification and cloning steps (Malik et al. 2008). A summary of the molecular methods used in monitoring microbial community composition and dynamics during bioremediation is presented in Table 2 .

Analysis of taxonomic and functional diversity in microbial populations

Microbial diversity and dynamics in environments such as soil undergoing bioremediation have been assessed by the analysis of conserved marker genes such as 16S rRNA genes. In addition, large databases of reference sequences, such as Greengenes, SILVA or Ribosomal Database Project II (RDP II) (Simon and Daniel 2011), provide an important and useful resource for rRNA gene-based classification of microorganisms. In addition, other conserved genes such as $\operatorname{rec} A$ or $\mathrm{radA}$ and genes encoding heat shock protein 70, elongation factor Tu or elongation factor $\mathrm{G}$ and hydrocarbon degradative enzymes (Peng et al. 2008; Flocco et al. 2009; Morales and Holben 2011) have been employed as molecular markers for phylogenetic analyses. The use of next-generation sequencing technologies, such as pyrosequencing of $16 \mathrm{~S}$ rRNA gene amplicons, has provided unprecedented sampling depth compared to traditional approaches, such as denaturing gradient gel electrophoresis (DGGE), terminal restriction fragment length polymorphism (T-RFLP) analysis or Sanger sequencing of 16S rRNA gene clone libraries (Rajendhran and Gunasekaran 2011). However, the intrinsic error rate of pyrosequencing may result in the overestimation of rare phylotypes. Each pyrosequencing read is treated as a unique identifier of a community member, and correction by assembly and sequencing depth, which is typically applied during genome projects, is not feasible. A crucial step in the taxonomic analysis of large metagenomic data sets is called binning. Within this step, the sequences derived from a mixture of different organisms are assigned to phylogenetic groups according to their taxonomic origins. Depending on the quality of the metagenomic data set and the read length of the DNA fragments, the phylogenetic resolution can range from the kingdom to the genus level. Currently, two broad categories of binning methods can be distinguished: similarity-based and compositionbased approaches. The similarity-based approaches classify DNA fragments based on sequence homology, which is determined by searching reference databases using tools like the Basic Local Alignment Search Tool (BLAST). Examples of bioinformatic tools employing similaritybased binning are the Metagenome Analyzer (MEGAN), CARMA, or the sequence ortholog-based approach for binning and improved taxonomic estimation of metagenomic sequences (Sort- ITEMS). CARMA assigns environmental sequences to taxonomic categories based on similarities to protein families and domains included in the protein family database (Pfam), whereas MEGAN and Sort-ITEMS classify sequences by performing comparisons against the NCBI nonredundant and NCBI nucleotide databases (Simon and Daniel 2011). These approaches are currently employed in microbial monitoring during hydrocarbon degradation and have been shown to yield resounding results. Surridge (2007) used PCR-DGGE, sequencing of $16 \mathrm{~S}, x y l E$ and $n d o B$ gene fragments (encoding dioxygenases) to characterize microbial communities in PAHs and polychlorinated biphenyl (PCB) contaminated soil. According to GenBank identification using BLAST, the bacteria Sphingomonas adhaesiva, Sphingomonas terrae, Sphingopyxis witflariensis, Sphingomonas sp., Methylocystis sp., Pseudomonas sp., Pseudomonas marginalis, Acidocella sp. and Acidiphilium facilis were among the dominant sequences in the PAH and PCB-polluted soils. Phylogenetic analysis with dendograms constructed using CLUST software also revealed diversity of aromatic hydrocarbon degradative genes that clustered the genera Burkholderia, Sphingomonas, Pseudomonas, Bacillus, Methylobacterium, Klebsiella and Rhodococcus as well as Vibrio together, thus describing the production of catechol 2,3 dioxygenase and naphthalene dioxygenase. By supplementing phylogenetic-based community dynamics tools with analysis of microbial community composition and diversity using specific catabolic gene markers, clearer information can be obtained on the behavior of the organisms that are specifically responsible for degrading hydrocarbons, free from variation in members of the community that do not directly participate in hydrocarbon degradation.

\section{Conclusion}

The clear-cut means for evaluating bioremediation of hydrocarbon-contaminated soils is a direct measurement of hydrocarbon dissipation or the residuum. However, the success of a bioremediation project can often be estimated by measuring the biodegradability of the contaminants. Because biodegradation is a microbial-driven process, it can be indirectly assessed by measuring the microbial numbers, biomass and/or activity. Methods that are used include enumeration of hydrocarbon degraders using any hydrocarbon as a selective pressure, measurement of community metabolic activities by respirometry or Biolog system, degradative enzyme-based assays, metagenomic/ nucleic acid-based techniques and phospholipid fatty acid analysis. Proper application of these strategies and techniques assists the investigators to monitor population dynamics during the course of bioremediation. 
Acknowledgments This study was funded by the Third World Organization for Women in Science (TWOWS) postgraduate fellowship and University of Port Harcourt Exchange and Linkage Programme with University of Pretoria, South Africa given to the corresponding author.

Open Access This article is distributed under the terms of the Creative Commons Attribution License which permits any use, distribution and reproduction in any medium, provided the original author(s) and source are credited.

\section{References}

Abed RM, Safi NM, Koster J, de Beer D, El-Nahhal Y, Rullkotter J, Garcia-Pichel F (2002) Microbial diversity of a heavily polluted microbial mat and its community changes following degradation of petroleum compounds. Appl Environ Microbiol 68:16741683

Abu GO, Chikere BO (2006) Cell surface properties of hydrocarbonutilizing bacterial isolates from Port Harcourt marine environment. Nig J Microbiol 20:809-816

Adoki A, Orugbani T (2007) Removal of crude petroleum hydrocarbons by heterotrophic bacteria in soils amended with nitrogenous fertilizer plant effluents. Afr J Biotech 6:1529-1535

Alexander M (1999) Biodegradation and bioremediation, 2nd edn. Academic Press, San Diego

Allen JP, Atekwana EA, Duris JW, Werkema DD, Rossbach S (2007) The microbial community structure in petroleum-contaminated sediments corresponds to geophysical signatures. Appl Environ Microbiol 73:2860-2870

Alquati C, Papacchini M, Riccardi C, Spicaglia S, Bestetti G (2005) Diversity of naphthalene-degrading bacteria from a petroleum contaminated soil. Annal Microbiol 55:237-242

Amouric A, Verhe F, Auria R, Casalot L (2006) Study of a hexanedegrading consortium in a biofilter and in liquid culture: biodiversity, kinetics and characterization of degrading strains. FEMS Microbiol Ecol 55:239-247

Atlas RM, Bartha R (1998) Microbial ecology: fundamentals and applications. 4th edn. Addison Wesley Longman, New York, pp 556-588

Atlas RM, Philp J (2005) Bioremediation: applied microbial solutions for real-world environmental cleanup. American Society for Microbiology (ASM) Press, Washington, DC, pp 78-105

Ayotamuno MJ, Kogbara RB, Ogaji SOT, Pobert SD (2006) Bioremediation of a crude oil polluted agricultural soil in Port Harcourt Nigeria. Appl Energy 83:1249-1257

Balba MT, Al-Awadhi R, Al-Daher R (1998) Bioremediation of oilcontaminated soil: microbiological methods for feasibility and field evaluation. J Microbiol Methods 32:155-164

Bartlett DH (1999) Microbial adaptations to the psychrosphere/ piezosphere. J Mol Microbiol Biotechnol 1:93-100

Bellon-Maurel W, Orliac O, Christen P (2003) Sensors and measurements in solid state fermentation: a review. Proc Biochem 38:881-896

Bogan BW, Lahner LM, Sullivan WR, Paterek JR (2003) Degradation of straight chain aliphatic and high molecular weight polycyclic aromatic hydrocarbons by a strain of Mycobacterium austroafricanum. J Appl Microbiol 94:230-239

Bordenave S, Fourcans A, Blanchard S, Goni MS, Caumette P, Duran R (2004a) Structure and functional analyses of bacterial communities changes in microbial mats following petroleum exposure. Ophelia 58:195-203
Bordenave S, Jezequel AR, Fourcans, Budzinski H, Merlin FX, Fourel T, Goni-Urriza M, Guyoneaud R, Grimaud R, Caumette P, Duran R (2004b) Degradation of the "Erika" oil. Aquat Living Resour 17:261-267

Bossert ID, Compeau GC (1995) Clean up of petroleum hydrocarbon contamination in soil. In: Young LY, Cerniglia CE (eds) Microbial transformation and degradation of toxic organic chemicals. Wiley, New York, pp 77-125

Bouchez-Naitali M, Rakatozafy H, Marchals R, Leveau JV, Vandecasteele JP (1999) Diversity of bacterial strains degrading hexadecane in relation to the mode of substrate uptake. J Appl Microbiol 86:421-428

Brons JK, van Elsas JD (2008) Analysis of bacterial communities in soil by use of denaturing gradient gel electrophoresis and clone libraries, as influenced by different reverse primers. Appl Environ Microbiol 74:2717-2727

Brown EJ, Braddock JF (1990) Sheen screen, a miniaturized mostprobable-number method for enumeration of oil-degrading microorganisms. Appl Environ Microbiol 56:3895-3896

Bundy JG, Paton GI, Campbell CD (2002) Microbial communities in different soil types do not converge after diesel contamination. J Appl Microbiol 92:288-976

Bundy JG, Paton GI, Campbell CD (2004) Combined microbial community level and single species biosensor responses to monitor recovery of oil polluted soil. Soil Biol Biochem 36:1149-1159

Cappello S, Caneso G, Zampino D, Monticelli L, Maimone G, Dnearo R, Tripod B, Troussellier M, Yakimov N, Giuliano L (2007) Microbial community dynamics during assays of harbour oil spill bioremediation: a microscale simulation study. J Appl Microbiol 102:184-194

Chaillan F, Le Fleche A, Bury E, Phantavong Y, Grimont P, Saliot A, Oudot J (2004) Identification and biodegradation potential of tropical aerobic hydrocarbon-degrading microorganisms. Res Microbiol 155:587-595

Chang YJ, Peacock AD, Long PE, Stephen JR, McKinley JP, Macnaughton SJ (2001) Diversity and characterization of sulfate-reducing bacteria in groundwater at a uranium mill tailings site. Appl Environ Microbiol 67:3149-3160

Chikere CB (2010) Bacterial diversity and community dynamics during the bioremediation of crude oil-polluted soil. $\mathrm{PhD}$ Thesis. Microbiology Department, University of Port Harcourt, Nigeria

Chikere BO, Chijioke-Osuji C (2006) Microbial diversity and physicochemical properties of a crude oil polluted soil. Nig J Microbiol 20:1039-1046

Chikere CB, Okpokwasili GC, Surridge AKJ, Cloete TE (2008a) Impact of oil contamination and biostimulation on bacterial diversity in soil microcosms. In: Proceedings of Department of Petroleum Resources 13th Health, Safety and Environment (HSE) Biennial International Conference on the Oil and Gas Industry in Nigeria, Abuja

Chikere CB, Okpokwasili GC, Surridge AKJ, Cloete TE (2008b) Population dynamics of indigenous bacteria during bioremediation of crude oil-polluted soil. In: Proceedings of Nigerian Society for Microbiology (NSM) 32nd Annual National Conference and General meeting, ABSU 2008

Chikere CB, Okpokwasili GC, Chikere BO (2009a) Bacterial diversity in a tropical crude oil-polluted soil undergoing bioremediation. Afr J Biotech 8:2535-2540

Chikere CB, Okpokwasili GC, Ichiakor O (2009b) Characterization of hydrocarbon utilizing bacteria in tropical marine sediments. Afr J Biotech 8:2541-2544

Chikere CB, Okpokwasili GC, Surridge AKJ, Cloete TE (2009c) Molecular approach to aerobic biodegradation of crude oil. In: Proceedings of Biotechnologies for Improved Production of Oil 
and Gas in the Gulf of Guinea (BIPOG3) 1st International Conference, Workshop and Exhibition, Abuja

Christensen H, Hansen M, Sørensen J (1999) Counting and size classification of active soil bacteria by fluorescence in situ hybridization with an rRNA oligonucleotide probe. Appl Environ Microbiol 65:1753-1761

Daly K, Dixon AC, Swanell RPJ, Lepo JE, Head IM (1997) Diversity among aromatic hydrocarbon-degrading bacteria and their meta cleavage genes. J Appl Microbiol 83:421-429

Delmont TO, Robe P, Cecillon S, Clark IM, Constancias F, Simonet P, Hirsch PR, Vogel TM (2011) Accessing the soil metagenome for studies of microbial diversity. Appl Environ Micrbiol 77:1315-1324

Drenovsky RE, Elliot GN, Graham KJ, Scow KM (2004) Comparison of phospholipids fatty acid (PLFA) and total soil fatty acid methyl esters (TSFAME) for characterizing soil microbial communities. Soil Biol Biochem 36:1793-1800

Ebuehi OAT, Abibo IB, Shekwolo PD, Iheagwam KS, Adoki A, Okoro IC (2005) Remediation of crude oil contaminated soil by enhanced natural attenuation technique. J Appl Sci Environ Mgt 9:103-105

Evans FF, Rosado AS, Sebastian GV, Casella R, Machado PLOA, Holmstrom C, Kjelleberg S, van Elsas JD, Seldin L (2004) Impact of oil contamination and biostimulation on the diversity of indigenous bacterial communities in soil microcosms. FEMS Microbiol Ecol 49:295-305

Flocco CG, Gomes NCM, Cormack WM, Smalla K (2009) Occurrence, diversity of naphthalene dioxygenase genes in soil microbial communities from the Maritime Antarctica. Environ Microbiol 11:700-714

Frostegard A, Tunlid A, Baath E (1993) Phospholipid fatty acid composition, biomass, and activity of microbial communities from two soil types experimentally exposed to different heavy metals. Appl Environ Microbiol 59:3605-3617

Fuller ME, Manning JF (2004) Microbiological changes during bioremediation of explosives-contaminated soils in laboratory and pilot-scale bioslurry reactors. Bioresour Technol 91:123-133

Ge Y, Zhang JB, Zhang LM, Yang M, He JZ (2008) Long-term fertilization regimes affect bacterial community structure and diversity of an agricultural soil in northern China. J Soils Sediments 8:43-50

Gentry TJ, Wickham GS, Schadt CW, He Z, Zhou J (2006) Microarray applications in microbial ecology research. Microb Ecol 52:159-175

Gontang EA, Fenical W, Jensen PR (2007) Phylogenetic diversity of Gram positive bacteria cultured from marine sediments. Appl Environ Microbiol 73:3272-3282

Graham JH, Hodge NC, Morton JB (1995) Fatty acid methyl ester profiles for characterization of glomalean fungi and their endomycorrhizae. Appl Environ Microbiol 61:58-64

Haack SK, Garchow H, Odelson DA, Forney LJ, Klug MJ (1994) Accuracy, reproducibility, and interpretation of fatty acid methyl ester profiles of model bacterial communities. Appl Environ Microbiol 60:2483-2493

Haack SK, Fogarty LR, West TG, Alm EW, McGuire JT, Long DT (2004) Spatial and temporal changes in microbial community structure associated with recharge-influenced chemical gradients in a contaminated aquifer. Environ Microbiol 6:438448

Hamamura N, Olson SH, Ward DM, Inskeep WP (2006) Microbial population dynamics associated with crude oil biodegradation in diverse soils. Appl Environ Microbiol 72:6316-6324

Heinzel E, Hedrich S, Janneck E, Glombitza F, Seifert J, Schlomann M (2009) Bacterial diversity in a mine water treatment plant. Appl Environ Microbiol 75:858-861
Heiss-Blanquet S, Benoit Y, Marechaux C, Monot F (2005) Assessing the role of alkane hydroxylase genotypes in environmental samples by competitive PCR. J Appl Microbiol 104:251-259

Higashioka Y, Kojima H, Sato S, Fukui M (2009) Microbial community analysis at crude oil-contaminated soils targeting the $16 \mathrm{~S}$ ribosomal RNA, xylM, C23O and bcr genes. J Appl Microbiol 107:126-135

Ijah UJJ, Antai SP (2003a) Removal of Nigerian light crude oil in soil over a 12-month period. Int Biodeterio Biodeg 51:93-99

Ijah UJJ, Antai SP (2003b) The potential use of chicken-drop microorganisms for oil spill remediation. The Environ 23:89-95

Itavaara M, Vikman M (1996) An overview of methods for biodegradability testing of biopolymers and packaging materials. J Environ Poly Degrad 4:29-36

Kamaludeen SP, Megharaj M, Naidu R, Singleton I, Juhasz AL, Hawke BG (2003) Microbial activity and phospholipid fatty acid pattern in long-term tannery waste-contaminated soil. Ecotoxicol Environ Saf 56:302-310

Kanaly RA, Harayama S (2000) Biodegradation of high molecularweight polycyclic aromatic hydrocarbons by bacteria. J Bacteriol 182:2059-2067

Kaplan CW, Kitts CL (2004) Bacterial succession in a petroleum land treatment unit. Appl Environ Microbiol 70:1777-1786

Kasai Y, Kishira H, Harayama S (2002) Bacteria belonging to the genus Cycloclasticus play a primary role in the degradation of aromatic hydrocarbons released in a marine environment. Appl Environ Microbiol 68:5625-5633

Kirk JL, Beaudette LA, Hart M, Moutoglis P, Klironomos JN, Lee H (2004) Methods of studying soil microbial diversity. J Microbiol Methods 58:169-188

Kleikemper J, Schroth MH, Sigler WV, Schmucki M, Bernasconi SM, Zeyer J (2002) Activity and diversity of sulfate-reducing bacteria in a petroleum hydrocarbon-contaminated aquifer. Appl Environ Microbiol 68:1516-1523

Kloos K, Munch JC, Schloter M (2006) A new method for the detection of alkane monooxygenase homologous genes (alkB) in soils based on PCR-hybridization. J Microbiol Methods 66:486-496

Kohring LL, Ringelberg DB, Devereux R, Stahl DA, Mittelman MW, White DC (1994) Comparison of phylogenetic relationships based on phospholipid fatty acid profiles and ribosomal RNA sequence similarities among dissimilatory sulphate-reducing bacteria. FEMS Microbiol Lett 119:303-308

Konstantinidis KT, Isaacs N, Fett J, Simpson S, Long DT, Marsh TL (2003) Microbial diversity and resistance to copper in metalcontaminated lake sediment. Microb Ecol 45:191-202

Koren O, Knezevic V, Ron EZ, Rosenberg E (2003) Petroleum pollution bioremediation using water-insoluble uric acid as the nitrogen source. J Appl Microbiol 69:6337-6339

Kozdroj J, van Elsas JD (2001) Structural diversity of microorganisms in chemically perturbed soil assessed by molecular and cytochemical approaches. J Microbiol Methods 43:197-212

Kumar M, Khanna S (2010) Diversity of 16S rRNA and dioxygenase genes detected in coal tar-contaminated site undergoing active bioremediation. J Appl Microbiol 108:1252-1262

Lal R, Pandey G, Sharma P, Kumari K, Malhotra S, Pandey R, Raina V, Kohler HPE, Holliger C, Jackson C, Oakeshott JG (2010) Biochemistry of microbial degradation of hexachlorohexane and prospects for bioremediation. Microbiol Mol Biol Rev 74:58-80

Langworthy DE, Stapleton RD, Sayler GS, Findlay RH (1998) Genotypic and phenotypic responses of a riverine microbial community to polycyclic aromatic hydrocarbon contamination. Appl Environ Microbiol 64:3422-3428

Leahy JG, Colwell RR (1990) Microbial degradation of hydrocarbons in the environment. Microbiol Rev 54:305-315 
Macnaughton SJ, Stephen JR, Venosa AO, Davis GA, Chang YJ, White DC (1999) Microbial population changes during bioremediation of an experimental oil spill. Appl Environ Microbiol 65:3566-3574

Maila MP (2005) Microbial ecology and bio-monitoring of total petroleum contaminated soil environments. PhD Thesis, Department of Microbiology and Plant Pathology, University of Pretoria, South Africa

Maila MP, Randima P, Surridge K, Drønen K, Cloete TE (2005) Evaluation of microbial diversity of different soil layers at a contaminated diesel site. Int Biodeterio Biodeg 55:39-44

Maila MP, Randima P, Drønen K, Cloete TE (2006) Soil microbial communities: influence of geographic location and hydrocarbon pollutants. J Soil Biol Biochem 38:303-310

Malik S, Beer M, Megharaj M, Naidu R (2008) The use of molecular tools to characterize the microbial communities in contaminated soil and water. Environ Int 38:265-276

Margesin R, Labbe D, Schinner F, Greer CW, Whyte LG (2003) Characterization of hydrocarbon degrading microbial populations in contaminated and pristine Alpine soils. Appl Environ Microbiol 69:3085-3092

Margesin R, Hammerle M, Tscherko D (2007) Microbial activity and community composition during bioremediation of diesel-oil contaminated soil: effects of hydrocarbon concentration, fertilizers and incubation time. Microb Ecol 55:259-269

Miller AK, Westergaard K, Christensen S, Sorensen SJ (2002) The diversity and function of soil microbial communities exposed to different disturbances. Microb Ecol 44:49-58

Mills AL, Breuil C, Colwell RR (1978) Enumeration of petroleumdegrading marine and estuarine microorganisms by the most probable number method. Can J Microbiol 24:552-557

Misko AL, Germida JJ (2002) Taxonomic and functional diversity of pseudomonads isolated from the roots of field-grown canola. FEMS Microbiol Ecol 42:399-407

Montiel C, Quintero R, Aburto J (2009) Petroleum biotechnology: technology trends for the future. Afr J Biotech 8:2653-2666

Morales SE, Holben WE (2011) Linking bacterial identities and ecosystem processes: can 'omic' analyses be more than the sum of their parts. FEMS Microbiol Ecol 75:2-16

Muyzer G, Smalla K (1998) Application of denaturing gradient gel electrophoresis (DGGE), temperature gradient gel electrophoresis (TGGE) in microbial ecology. Antonie Van Leeuwenhoek 73:127-141

Nannipieri P, Ascher J, Ceccherini MT, Landi L, Pietramellara G, Renella G (2003) Microbial diversity and soil function. Eur J Soil Sci 54:655-670

Neufeld JD, Dumont MG, Vohra J, Murrell JC (2007) Methodological considerations for the use of stable isotope probing in microbial ecology. Microb Ecol 53:442-453

Nogales BMP, Lanfranconi JM, Pina-Villalonga, Bosch R (2011) Antropogenic perturbations in marine microbial communities. FEMS Microbiol Rev 35:275-298

Nweke CO, Okpokwasili GC (2004) Effects of bioremediation treatments on the bacterial populations of soil at different depths. Nig J Microbiol 18:363-372

Obayori SO, Salam LB (2010) Degradation of polycyclic aromatic hydrocarbons: role of plasmids. Sci Res Ess 5:4093-4106

Odokuma LO, Dickson AA (2003) Bioremediation of a crude oilpolluted tropical rain forest soil. Glob J Environ Sci 2:2940

Odokuma LO, Ibor MN (2002) Nitrogen fixing bacteria enhanced bioremediation of a crude oil polluted soil. Glob J Pure Appl Sci $86: 455-468$

Ogram A, Castro H, Chauhan A (2007) Methods of soil microbial community analysis. In: Hurst CJ, Crawford RL, Garland JL, Lipson DA, Mills AL, Stetzenbach LD (eds) Manual of
Environmental Microbiology, 3rd edn. American Society for Microbiology (ASM) Press, Washington, DC, pp 652-662

Okpokwasili GC (2006) Microbes and the Environmental Challenge. Inaugural lecture series No. 53. University of Port Harcourt Press. Port Harcourt, pp 1-77

Okpokwasili GC, Odokuma LO (1994) Tolerance of Nitrobacter to toxicity of some Nigerian crude oils. Bull Environ Contam Toxicol 52:388-395

Okpokwasili GC, Somerville CC, Sullivan M, Grimes DJ, Colwell RR (1986) Plasmid mediated degradation of hydrocarbons in estuarine bacteria. Oil Chem Pollut 3:117-129

Ollivier B, Magot B (2005) Petroleum Microbiology. American Society for Microbiology (ASM) Press, Washington, DC

Peng R, Xiong A, Sue Y, Fu X, Gao F, Zhao W, Tian Y, Yao Q (2008) Microbial biodegradation of polyaromatic hydrocarbons. FEMS Microbiol Rev 32:927-955

Philp JC, Whitely AS, Ciric L, Bailey MJ (2005) Monitoring bioremediation. In: Atlas RM, Philp J (eds) Bioremediation: applied microbial solutions for real-world environmental cleanup. American Society for Microbiology (ASM) Press, Washington, DC, pp 237-292

Pombo SA, Kleikemper J, Schroth MH, Zeyer J (2005) Field-scale isotopic labelling of phospholipid fatty acids from acetatedegrading sulfate-reducing bacteria. FEMS Microbiol Ecol 51:197-207

Popp N, Schlomann M, Mau M (2006) Bacterial diversity in the active stage of a bioremediation system for mineral oil hydrocarbon-contaminated soils. Microbiology 152:3291-3304

Prince RC (2005) The microbiology of marine oil spill bioremediation. In: Ollivier B, Magot B (eds) Petroleum Microbiology. American Society for Microbiology (ASM) Press, Washington, DC, pp 317-335

Prince R, Atlas RM (2005) Bioremediation of marine oil spills. In: Atlas RM, Philp J (eds) Bioremediation: applied microbial solutions for real-world environmental cleanup. American Society for Microbiology (ASM) Press, Washington, DC, pp 269-292

Qiao N, Shao Z (2010) Isolation and characterization of a novel biosurfactant produced by hydrocarbon degrading bacterium Alcanivorax dieselolei B-5. J Appl Microbiol 108:1207-1216

Quatrini P, Scaglione G, De Pasquale C, Reila S, Puglia AM (2008) Isolation of Gram-positive $n$-alkane degraders from a hydrocarbon contaminated Mediterranean shoreline. J Appl Microbiol 104:251-259

Rajendhran J, Gunasekaran P (2011) Microbial phylogeny and diversity: small subunit ribosomal RNA sequence analysis and beyond. Microbiol Res 166:99-110

Ringelberg DB, Talley JW, Perkins EJ, Tucker SG, Luthy RG, Bouwer EJ (2001) Succession of phenotypic, genotypic, and metabolic community characteristics during in vitro bioslurry treatment of polycyclic aromatic hydrocarbon-contaminated sediments. Appl Environ Microbiol 67:1542-1550

Rodrigues DF, Sakata SK, Comasseto JV, Bicego MC, Pellizari VH (2009) Diversity of hydrocarbon-degrading Klebsiella strains isolated from hydrocarbon-contaminated estuaries. J Appl Microbiol 106:1304-1314

Rojas-Avelizapa NG, Roldan-Carrillo T, Zegarra-Martinez H, Munoz-Colunga AM, Fernandez-Linares LC (2007) A field trial for an ex-situ bioremediation of a drilling mud-polluted site. Chemosphere 66:1595-1600

Rojo F (2009) Degrdadation of alknaes by bacteria. Environ Microbiol 11:2477-2490

Roling WFM, Milner MG, Jone DM, Lee K, Daniel F, Swannell RPJ, Head IM (2002) Robust hydrocarbon degradation and dynamics of bacterial communities during nutrient-enhanced oil spill bioremediation. Appl Environ Microbiol 68:5537-5548 
Roling WFM, Milner MG, Jones DM, Fratepietro F, Swannell RPJ, Daniel F, Head IM (2004) Bacterial community dynamics and hydrocarbon degradation during a field scale evaluation of bioremediation in a mudflat beach contaminated with buried oil. Appl Environ Microbiol 70:2603-2613

Rosenberg E, Ron EZ (1996) Bioremediation of petroleum contamination. In: Crawford RL, Crawford DL (eds) Bioremediation: principles and application. Cambridge University Press, Cambridge, pp 100-124

Rosenberg E, Legman R, Kushmaro A, Taube R, Adler E, Ron EZ (1992) Petroleum bioremediation: a multi phase problem. Biodegradation 3:337-350

Rosenberg E, Legman R, Kushmaro A, Adler E, Abir H, Ron EZ (1996) Oil bioremediation using insoluble nitrogen source. J Biotechnol 51:273-278

Rosenberg E, Navon-Venezia S, Zilber-Rosenberg I, Ron EZ (1998) Rate-limiting steps in the microbial degradation of petroleum hydrocarbons. In: Rubin H, Narkis N, Carberry J (eds) Soil and aquifer pollution. Springer, Berlin, pp 159-171

Ruberto L, Dias R, Balbo AL, Vazquez SC, Hernandez EA, Cormack WPM (2009) Influence of nutrients addition and bioaugmentation on the hydrocarbon biodegradation of a chronically contaminated Antarctic soil. J Appl Microbiol 106:1101-1110

Sarkar D, Ferguson M, Datta R, Birnbaum S (2005) Bioremediation of petroleum hydrocarbons in contaminated soils: comparison of biosolids addition, carbon supplementation, and monitored natural attenuation. Environ Pollut 136:187-195

Schlegel HG (2002) General microbiology, 7th edn. Cambridge University Press, Cambridge, pp 470-477

Schryver JC, Brandt CC, Pfiffner SM, Palumbo AV, Peacock AD, White DC (2006) Application of nonlinear analysis methods for identifying relationships between microbial community structure and groundwater geochemistry. Microb Ecol 51:177-188

Sei K, Sugimoto Y, Mori K, Maki H, Kohno T (2003) Monitoring of alkane degrading bacteria in a sea water microcosm during crude oil degradation by polymerase chain reaction-based on alkanecatabolic genes. Environ Microbiol 5:517-522

Semple KT, Doick KJ, Jones KC, Burauel P, Craven A, Harms H (2004) Defining bioavailability and bioaccessibility of contaminated soil and sediment is complicated. Environ Sci Technol 38:228-231

Siciliano SD, Germida JJ, Banks K, Greer CW (2003) Changes in microbial community composition and function during a polyaromatic hydrocarbon phytoremediation field trial. Appl Environ Microbiol 69:483-489

Simon C, Daniel R (2011) Metagenomic analysis: past and present. Appl Environ Microbiol 77:1153-1161

Smalla K, Oros-Sichler M, Milling A, Heuer H, Baumgarte S, Becker R, Neuber G, Kropf S, Ulrich A, Tebbe CC (2007) Bacterial diversity of soils assessed by DGGE, T-RFLP and SSCP fingerprints of PCR-amplified 16S rRNA gene fragments: do the different methods provide similar results? J Microbiol Methods 69:470-479

Snyder L, Champness W (2007) Molecular genetics of bacteria, 3rd edn. American Society for Microbiology (ASM) Press, Washington, DC

Stroud JL, Paton GI, Semple KT (2007) Microbe-aliphatic hydrocarbon interactions in soil; implications for biodegradation and bioremediation. J Appl Microbiol 102:1239-1253

Surridge AKJ (2007) Denaturing gradient gel electrophoresis characterisation of microbial communities in polycyclic aromatic hydrocarbon and polychlorinated biphenyl contaminated soil. PhD Thesis, Department of Microbiology and Plant Pathology, University of Pretoria, South Africa

Swannell RPJ, Lee K, McDonagh M (1996) Field evaluations of marine oil spill bioremediation. Microbiol Rev 60:342-365
Torsvik V, Øvreås L (2007) Microbial phylogeny and diversity in soil. In: van Elsas JD, Janxxon JK, Trevors JK (eds) Modern soil microbiology, 2nd edn. CRC Press, New York, pp 24-49

van Elsas JD, Jansson JK, Trevors JK (2007) Modern soil microbiology, 2nd edn. CRC Press, New York, pp 387-429

van Hamme JD, Singh A, Ward OP (2003) Recent advances in petroleum microbiology. Microbiol Mol Biol Rev 67:503-549

Venosa AD, Suidan MT, Wrenn BA, Strohmeier KL, Haines JR, Eberhart BL, King D, Holder E (1996) Bioremediation of an experimental oil spill on the shoreline of Delaware Bay. Environ Sci Technol 30:1764-1775

Vestal JR, White DC (1989) Lipid analysis in microbial ecology: quantitative approaches to the study of microbial communities. Bioscience 39:535-541

Vinas M, Sabate J, Espuny MJ, Solanas AM (2005) Bacterial community dynamics and polycyclic aromatic hydrocarbon degradation during bioremediation of heavily creosote-contaminated soil. Appl Environ Microbiol 71:7008-7018

Watanabe K (2001) Microorganisms relevant to bioremediation. Curr Opin Biotechnol 12:237-241

Watanabe K, Hamamura N (2003) Molecular and physiological approaches to understanding the ecology of pollutant degradation. Curr Opin Microbiol 14:289-295

Watanabe K, Kodama Y, Syutsubo K, Harayama S (2000) Molecular characterization of bacterial populations in petroleum-contaminated groundwater discharged from underground crude oil storage cavities. Appl Environ Microbiol 66:4803-4809

Widmer F, Fliessbach A, Laczko E, Schulze-Aurich J, Zeyer J (2001) Assessing soil biological characteristics: a comparison of bulk soil community DNA-, PLFA-, and Biolog ${ }^{\mathrm{TM}}$-analyses. Soil Biol Biochem 33:1029-1036

Williams CM, Grimes JL, Mikkelsen RL (1999) The use of poultry litter as co-substrate and source of inorganic nutrients and microorganisms for the ex-situ biodegradation of petroleum compounds. Poult Sci 78:956-964

Wolicka D, Suszek A, Borkowski A, Bielecka A (2009) Application of aerobic microorganisms in bioremediation in situ of soil contaminated by petroleum products. Biores Technol 100:3221-3227

Wrenn BA, Venosa AD (1996) Selective enumeration of aromatic and aliphatic hydrocarbon-degrading bacteria by a most-probable number procedure. Can J Microbiol 42:252-258

Yakimov MM, Timmis KN, Golyshin PN (2007) Obligate oil degrading marine bacteria. Curr Opin Biotechnol 18:257-266

Young LY, Cerniglia CE (1995) Microbial transformation and degradation of toxic organic chemicals. Wiley, New York, pp $77-125$

Zeinali M, Vossoughi M, Ardestani SK, Babanezhad E, Masoumian M (2007) Hydrocarbon degradation by thermophilic Nocardia otitidiscaviarum strain TSH1: physiological aspects. J Basic Microbiol 47:534-539

Zelles L (1999) Fatty acid patterns of phospholipids and lipopolysaccharides in the characterization of microbial communities in soil: a review. Biol Fertil Soils 5:111-129

Zelles L, Bai QY (1993) Fractionation of fatty acids derived from soil lipids by solid phase extraction and their quantitative analysis by GC-MS. Soil Biol Biochem 25:495-507

Zengler K (2008) Accessing uncultivated microorganisms: from the environment to organisms and genomes and back. American Society for Microbiology Press, Washington, DC, pp 153-186

Zucchi N, Angiolini L, Borin S, Brusetti L, Dietrich N, Gigliotti C, Barbieri P, Sorlini C, Daffonchio D (2003) Response of bacterial community during bioremediation of an oil-polluted soil. J Appl Microbiol 94:248-257 